\title{
コンクリート中の鋼材のマクロセル腐食 に関する解析手法の構築
}

\author{
丸屋 剛 1 ・武田 均 2 ・堀口 賢一 2 -小山 哲 ${ }^{3}$ 許 鎧麟 4 \\ 1正会員 大成建設(株) 技術センター土木技術研究所（†245-0051 横浜市戸塚区名瀬町344-1） \\ E-mail:tsuyoshi.maruya@sakura.taisei.co.jp \\ 2正会員 大成建設(株) 技術センター土木技術研究所（干245-0051 横浜市戸塚区名瀬町344-1） \\ 3 (株)篠塚研究所（†160-0023 新宿区西新宿4-5-1 幸伸ビル $3 \mathrm{~F}$ ） \\ ${ }^{4}$ Member of JSCE, National Kaohsiung First University of Science and Technology, Taiwan
}

\begin{abstract}
本研究は, 塩化物イオンにより促進されるコンクリート中の鋼材の腐食をマクロセル回路の形成による 腐食ととらえ, それに基づき腐食量の分布を算出する解析手法を構築し, 乾湿繰返し環境に暴露した供試 体中の鉄筋の腐食をシミュレートしてその妥当性を検証したものである.ミクロセル回路形成におけるア ノード分極曲線とカソード分極曲線を塩化物イオン濃度などの腐食因子を要因として定式化し, 得られた ミクロセル回路の自然電位の差によりマクロセルが形成されるものとした. 解析上の自然電位および腐食 量の分布は供試体の測定結果と定性的に一致しており，本論文の腐食進行に関する解析手法の妥当性が明 らかとなった。 また, 断面修復部などにおけるマクロセル回路の形成について解析的に明らかにした。
\end{abstract}

Key Words :reinforced concrete, micro-cell corrosion, macro-cell corrosion, half-cell potential current density, corrosion rate, analysis method

\section{1. はじめに}

コンクリート中の鋼材の腐食は, 中性化の進行や塩 化物イオンによる不動態被膜の破壊により開始し，酸 素の供給により進行する. しかし, 腐食が進展しても, コンクリート表面に直ちにひび割れが発生するのでは なく, ある腐食量に達寸るとひび割れが表面に現れる。 さらに, この腐食ひび割れを通して, 塩化物イオンや 酸素がコンクリート中に浸透することにより, 腐食は 加速的に促進され, 構造物に要求される安全性が損な われる劣化に至る.これらの劣化進行過程は, 潜伏期, 進展期, 加速期, 劣化期と区分されるのが一般的であ り 1)，鋼材に腐食が発生するまでの潜伏期であれば, 鋼材の腐食による而久性は問題ない，また，コンクリ 一ト中の鋼材に腐食が発生しても, 進展期であればコ ンクリートの安全性は一般に損なわれないことから, 進展期の終了時期を適切に評価することが, 安全性の 評価のみならず，構造物の予防保全的な維持管理にも 重要である. そのためには, 鋼材の腐食速度を定量化 することが必要となる.

本論文は，コンクリート中の鋼材の腐食速度や腐食 量を算出する解析手法を述べたものである. 著者らは すでに, コンクリート中の鋼材の腐食進行と腐食の進 行にともなうひび割れの発生を算出するためのアウト ラインを示しており 2), 本論文は塩化物イオンの存在
下におけるマクロセル回路の形成とそれに基づく腐食 速度の増大について, 暴露実験の結果の考察などを含 めて詳細に論じたものである，なお，腐食によるひび 割れの発生や，腐食ひび割れによる腐食の促進につい ては本論文内容の対象外とする.

マクロセル回路とは，アノードとカソードがある程 度離れた位置に形成される腐食電流回路のことであり， 土中の鋼材の腐食モデルとしても研究されている3). 一方，ミクロセルとはアノードとカソードがごく近傍 に形成される回路で，同一位置と見なしてもよい，コ ンクリート中の鋼材の腐食に関する研究は国内外を問 わず既に膨大な数に及んでいるが 4)，マクロセル回路 の形成を主題として腐食速度を定量化したものは多く はない 5),6),7),8). その理由としては, 鋼材素材の腐食現 象はミクロセル回路の観点から考えることが多く, 実 験的にも比較的容易にモデルの検証ができることが考 えられる.しかし, コンクリート中に埋め込まれた鋼 材のように, 腐食の進行に不均一性が存在するとアノ 一ド部の腐食速度は急激に増加することは経験的にも 知られており，ひび割れ近傍で腐食の進行が顕著であ ることや，断面修復した場合など，その付近の未修復 部分で腐食の進展が顕著になることがその例として挙 げられる。このことから，マクロセル腐食現象を解明 することは，コンクリート中の鋼材の腐食現象を理解 し, 腐食進行を適確に予測する上で極めて重要となる。 


\section{2.コンクリート中の鋼材の腐食進行に関する解 析手法の全体構成}

本章では，コンクリート中の鋼材の腐食をミクロセ ル回路の形成と, それによる自然電位の差に起因する マクロセル回路の形成に基づき進行する現象としてと らえ, 腐食の進行を定量的に評価するための解析手法 の全体構成について論じる.

\section{（1）鋼材の腐食量算出までの解析フロー}

コンクリート中の鋼材の腐食速度は，腐食電流に関 するマクロセル回路の形成により大きく増大するため, 一般に考えられるような鋼材の腐食のように，アノー ド分極曲線とカソード分極曲線との交点としてそれを 求めるだけでは電流密度を過小に評価することになり 適切な評価をしたことにはならない9). けだし, 理論 的にも実用的にもマクロセル回路における腐食速度の 算出モデルが必要となる所以である.

解析手法の概要を計算のフロー図として図-1 に示 す.まず，コンクリート中の物質移動の解析から, 経 時変化する鋼材位置における塩化物イオン濃度 10) と 酸素量 ${ }^{11)}$ を計算する. これらの值を用いて，ミクロセ ル腐食モデルによりミクロセル回路による自然電位 $\left(\mathrm{E}_{\text {micro }}\right)$ を計算する。ここでいうミクロセル腐食モデル とは, Evans のダイアグラム上で, 鋼材位置の塩化物 イオン濃度と水酸化物イオン濃度の比率 $\left(\left[\mathrm{Cl}^{-}\right] /\left[\mathrm{OH}^{-}\right]\right)$ などの関数としたアノード分極曲線と, 鋼材位置での 酸素量などの関数としたカソード分極曲線の交点とし て, ミクロセル回路における自然電位 $\left(\mathrm{E}_{\mathrm{micro}}\right)$ と電流密 度 $\left(\mathrm{I}_{\text {micro }}\right)$ を求めるものである.

次に，マクロセル腐食モデルにより，ミクロセル回 路における自然電位 $\left(\mathrm{E}_{\text {micro }}\right)$ からマクロセル回路による 自然電位 $\left(\mathrm{E}_{\text {macro }}\right)$ と電流密度を計算する。ここでいうマ クロセル腐食モデルとは，ミクロセル腐食モデルによ り求めた鋼材上の 2 要素間における自然電位の差によ りその 2 要素間に電流が流れ，鋼材の分極状態がミク ロセル形成時とは異なる状態になることにより，その 2 要素間に新たに形成された電流回路が示す自然電位 と電流密度を算定するものである。

ここまでは，鋼材の任意の 2 要素間に形成されるマ クロセル回路による自然電位 $\left(\mathrm{E}^{\prime}{ }_{\text {macro }}\right)$ と電流密度 (I' $\left.{ }_{\text {macro }}\right)$ であるが, 鋼材上のある 1 要素に注目した場合 に，その 1 要素とマクロセル回路を形成する対要素の 組合わせを考慮して, ある 1 要素における自然電位 $\left(\mathrm{E}_{\text {macro }}\right)$ および電流密度 $\left(\mathrm{I}_{\text {macro }}\right)$ を算出しなければならな い. これをマルチサーキットモデルとよぶ. 各要素に おける電流密度 $\left(\mathrm{I}_{\text {macro }}\right)$ が計算されると, ファラデーの 法則を用いて腐食量を算出することができる.

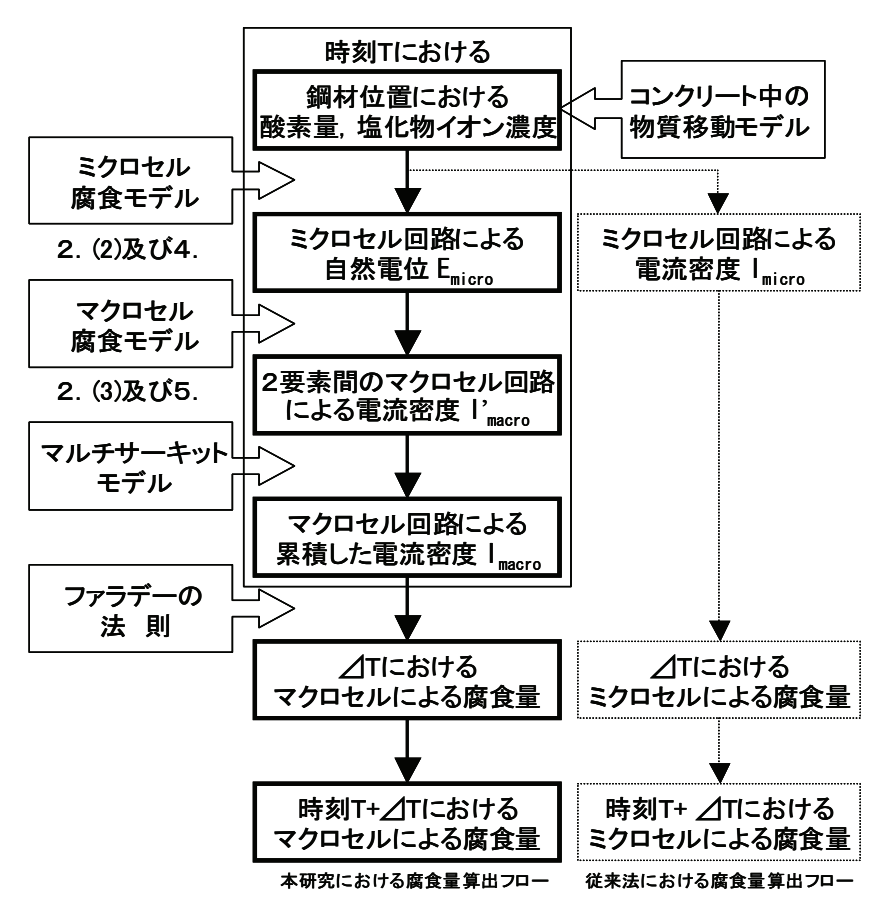

図-1 鋼材の腐食量算出までの解析フロー

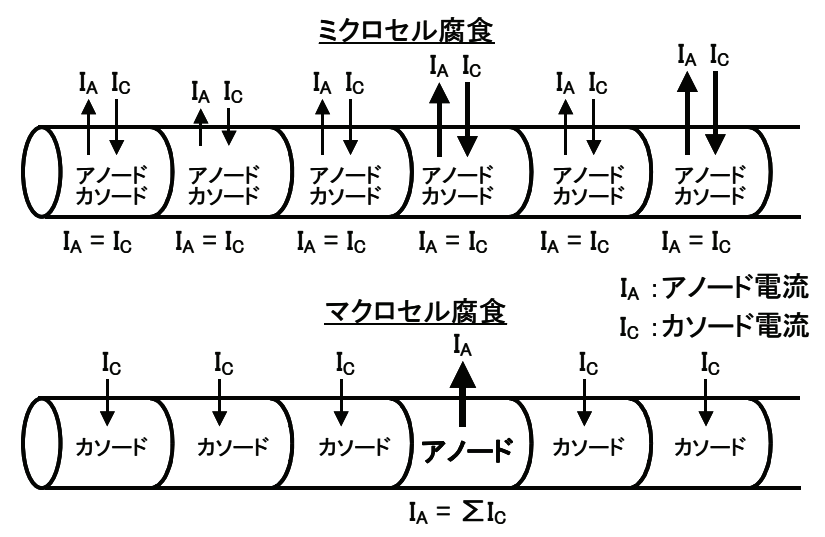

図-2 ミクロおよびマクロにおける腐食電流の流れ

\section{（2）ミクロセル腐食モデルの考案}

ミクロセル腐食とは, 図-2 に示すように鋼材上の任 意の要素それぞれにおいて鋼材からコンクリートに流 出するアノード電流と, コンクリートから鋼材に流入 するカソード電流が等しい状態として腐食現象を腐食 電流回路としてとらえたものである 2). したがって, 各要素にアノード部とカソード部が存在することにな る.ミクロセル腐食モデルは，図-3 に示すような Evans のダイアグラム上で考えることができる. 図中 の $\mathrm{A}, \mathrm{A}_{1}, \mathrm{~A}_{2}, \mathrm{~A}_{3}$ は塩化物イオン濃度が異なるときのア ノード分極曲線を表しており，A は塩化物イオンが存 在しない場合， $A_{1}, A_{2}, A_{3}$ はそれらの順で塩化物イオ ン濃度が高くなる場合である. B およびC はカソード 分極曲線であり，Bが酸素の供給が十分な場合，Cが酸 素の供給が不足する場合である. 


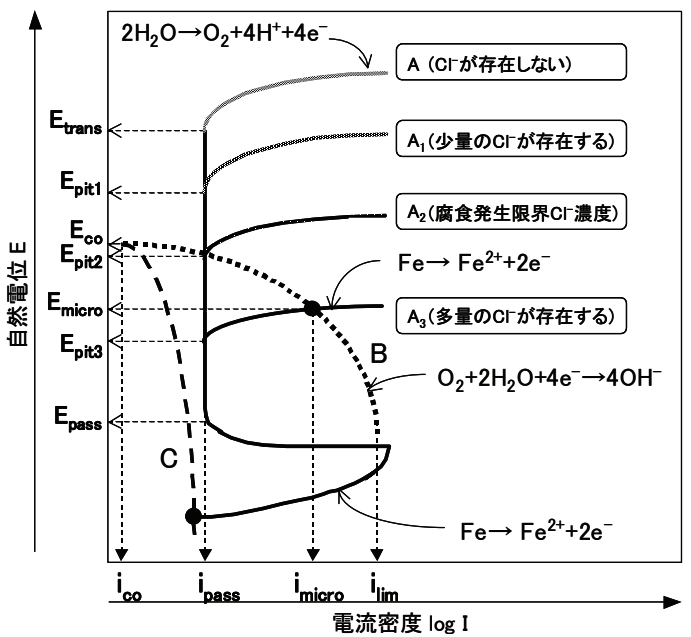

図-3 アルカリ存在下でのミクロセル腐食モデル

図-3 の横軸である電流密度に関して, $\mathrm{i}_{\mathrm{co}}$ はカソード 反応の交換電流密度を， $\mathrm{i}_{\text {pass }}$ は不動態被膜形成時の電 流密度を, $i_{\text {micro }}$ はアノード分極曲線 $A_{3}$ とカソード分極 曲線 B の交点としてのミクロセル回路形成にともなう 電流密度を, $i_{\mid \text {im }}$ は酸素の供給量によって決まる限界 電流密度を表したものである.また, 縦軸に関しては, $\mathrm{E}_{\mathrm{co}}$ はカソード反応の平衡電位を, $\mathrm{E}_{\mathrm{trans}}$ は塩化物イオン が存在せず電解溶液がアルカリ性であるときの孔食電 位を, $E_{p i t 1}, E_{p i t 2}, E_{p i t 3}$ は電解溶液の塩化物イオン濃度 がこの順に高くなるときの孔食電位を， $\mathrm{E}_{\text {micro }}$ はアノー ド分極曲線 $A_{3}$ とカソード分極曲線 $B$ の交点としてのミ クロセル回路形成にともなう電位を表したものである.

ミクロセル腐食では, 図-2に示したようにアノード 電流とカソード電流の值が等しくなるように要素内で 電流が流れ一定の自然電位となるが，これは図-3では アノード分極曲線とカソード分極曲線の交点の值にな ることと同值なことである. 図-3 からわかるように， 鋼材位置における塩化物イオン濃度が腐食発生塩化物 イオン濃度以下の場合には，アノード分極曲線は A, $A_{1}, A_{2}$ となり, 酸素の供給が十分な場合でもカソード 分極曲線 $B$ との交点は, 横軸の電流密度の值が不動態 電流密度 $\mathrm{i}_{\text {pass }}$ となる. しかし, 鋼材位置における塩化 物イオン濃度が腐食発生塩化物イオン濃度以上の場合 には，すなわち鋼材の不動態被膜が破壊された状態で はアノード分極曲線は $A_{3}$ となり, カソード分極曲線 $B$ との交点は横軸の電流密度の值が $\mathrm{i}_{\text {micro }}$ となる.ここで, $\mathrm{i}_{\text {pass }}$ 《 $\mathrm{i}_{\text {micro }}$ の関係があることから, 不動態被膜が破 壊された後の腐食速度は極めて大きくなり，逆にいえ ば不動態被膜の形成により腐食速度は著しく小さくな ることが概念的に理解される.

\section{（3）マクロセル腐食モデルの考案}

マクロセル腐食とは, 図-2 に示すように鋼材上のア

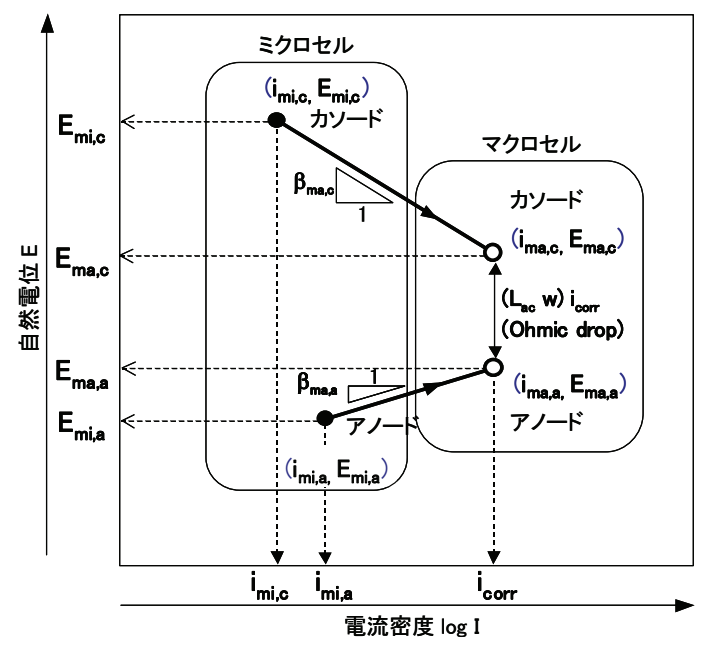

図-4マクロセル腐食モデルの概念図

ノードの位置とカソードの位置が分離し，腐食回路が マクロに形成されるとして腐食現象をとらえたもので ある 2)。マクロセル腐食モデルも，図-4 に示すような Evans のダイアグラム上で考えることができる. ミク ロセルモデルで計算される点は，図-4 に示すミクロセ ルの枠内のカソードとアノードの 2 点(の)である.こ こで，任意の 2 点のうち電位の高い方がカソードに低 い方がアノードになる。この 2 点間に電流が流れる場 合，すなわちマクロセル回路が形成されると分極状態 が変化し，図に示すマクロセルの枠内のカソードとア ノードの 2 点 $(\bigcirc)$ に座標がそれぞれ移動する。なお， マクロセル回路が形成されるのは，ミクロセル回路に おけるアノードおよびカソードの電流密度が不動態電 流密度以上のときとした。

ミクロセルモデルにより計算されるカソードの電 流密度を $\mathrm{i}_{\mathrm{mi}, \mathrm{c}}$, 自然電位を $\mathrm{E}_{\mathrm{mi}, \mathrm{c}}$, アノノードの電流密度を $\mathrm{i}_{\mathrm{mi}, \mathrm{a}}$, 自然電位を $\mathrm{E}_{\mathrm{mi}, \mathrm{a}}$ とすると，マクロセル回路形成 後のカソードの電流密度を $\mathrm{i}_{\mathrm{ma}, \mathrm{c}}$, 自然電位を $\mathrm{E}_{\mathrm{ma}, \mathrm{c}}$, ア ノードの電流密度を $\mathrm{i}_{\mathrm{ma}, \mathrm{a}}$, 自然電位を $\mathrm{E}_{\mathrm{ma}, \mathrm{a}}$ とするアノ ードとカソード間に流れる電流が同じ值（ $\left.i_{\text {ma, }}=i_{m a, a}\right)$ となるように分極状態が変化し，これをマクロセル回 路形成による腐食電流密度 $\mathrm{i}_{\text {corr }}$ とする.

マクロセル回路形成後のカソードとアノード間に 流れる電流は，これらの間のコンクリート抵抗や分極 抵抗に支配され，式(1)に示すような関係となる.

$$
E_{m a, c}-E_{m a, a}=\left(L_{a c} \cdot w\right) \cdot i_{c o r r}
$$

ここに, $E_{m a, c}, E_{m a, a}:$ 自然電位 $(\mathrm{V}), L_{a c}:$ アノードとカソ 一ドの距離 $(\mathrm{cm}), w:$ : ロセル回路が形成される部分 のコンクリートの見掛けの比抵抗 $(\Omega \mathrm{cm}), i_{\text {corr }}$ :電流密度 $\left(\mathrm{A} / \mathrm{cm}^{2}\right)$ である。

また，式(1)で表した意味は，ミクロセル腐食モデ 
ルにより計算される值と, 図-4に示すマクロセル回路 形成にともなう分極曲線の傾きを用いて式(2)として も表すことができる.

$$
\begin{aligned}
E_{m a, c}-E_{m a, a}=\left(E_{m i, c}+\beta_{m a, c} \log \left(i_{c o r r} / i_{m i, c}\right)\right) \\
-\left(E_{m i, a}+\beta_{m a, a} \log \left(i_{\text {corr }} / i_{m i, a}\right)\right)
\end{aligned}
$$

ここに， $\beta_{m a, c}:$ :マロセル回路形成にともなうカソー ド分極曲線の傾き, $\beta_{m a, a}$ :マクロセル回路形成にともな うアノード分極曲線の傾き，である。

また，図-4からわかるように，ミクロセル回路から マクロセル回路に移行する際の電位変化には，マクロ セル回路形成にともなう分極による電位変化分も含ま れており，コンクリート抵抗による電位変化だけを考 慮したものではない.

\section{（4）マルチサーキットモデルの考案}

図-4 に示寸マクロセル腐食モデルは，図-2 に示寸 アノードとカソードの任意の 2 要素間でのマクロセル の形成をモデル化したものであるが，ある要素（図-5 に示す i）に注目した場合，任意の 2 要素間の対（図 -5 に示寸 $\mathrm{i}$ と $\mathrm{j}$ の対) は複数ある. したがって，これ らすべての 2 要素の対についてマクロセル腐食モデル を適用して, 各要素における自然電位と電流密度を算 出することとした. 図-6 に示寸ミクロセルの点線の枠 内（A 系列データ：右下がりの○印の点列）は，ミク ロセルモデルにより計算された各要素の值であり，こ の例では自然電位が最も小さい要素を注目要素とした。 これらにマクロセルモデルを適用すると，例えば注目 要素 $\mathrm{i}$ はミクロセルの状態では自然電位が最も小さい 要素であることから，2 要素間マクロセルモデルにお いてす心゙ての対関係でアノードになり, 注目要素 $\mathrm{i} の$ 対要素 $\mathrm{j}$ に対するマクロセル回路形成後の座標は 2 要 素間マクロセルの点線の枠内の点の集合（B 系列デー 夕：右上がりの口印の点列）となる. 図-4 を用いて説 明すると, 注目要素 $\mathrm{i}$ の座標は $\left(\mathrm{i}_{\mathrm{mi}, \mathrm{a}}, \mathrm{E}_{\mathrm{mi}, \mathrm{a}}\right)$ であり, 対 要素の数だけの座標 $\left(i_{\mathrm{mi}, a}, \mathrm{E}_{\mathrm{mi}, \mathrm{o}}\right)$ が $\mathrm{A}$ 系列データであり, マクロセル形成後の $B$ 系列データは対要素 $\left(\mathrm{i}_{\mathrm{ma}, \mathrm{a}}, \mathrm{E}_{\mathrm{ma}, \mathrm{a}}\right)$ の集合である. 注目要素 $\mathrm{i}$ のマクロセル回路形成後の 自然電位はマクロセルモデルで計算される要素対ごと の自然電位を平均することで, 電流密度は要素対ごと の電流の総和を求め注目要素の表面積で除寸ることに より求める.

ただし，図-6に示すように，2 要素間のマクロセル 回路形成後の電流密度は，コンクリート抵抗が大きい 場合などでミクロセル回路が形成されていたときより も計算上小さくなることもあるが，これらを総和する マクロセル腐食モデルでは分極状態がこのように恋化

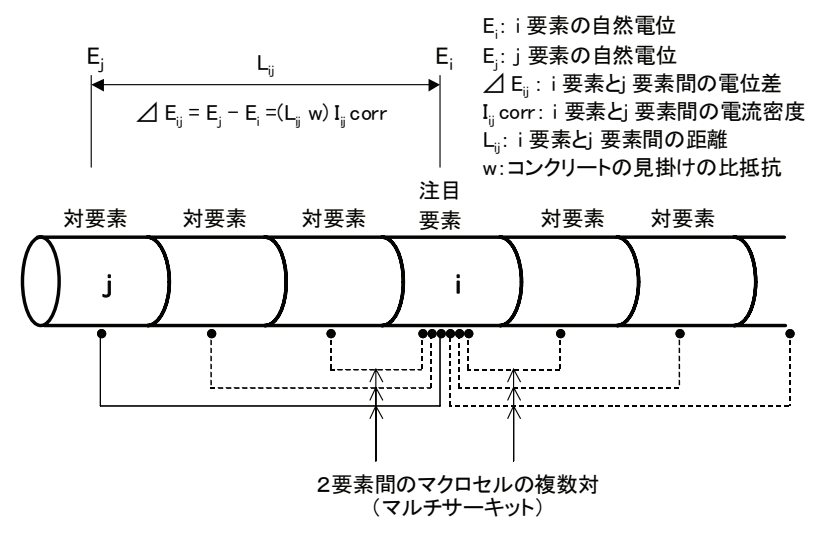

図-5 マクロセル腐食モデルの考え方

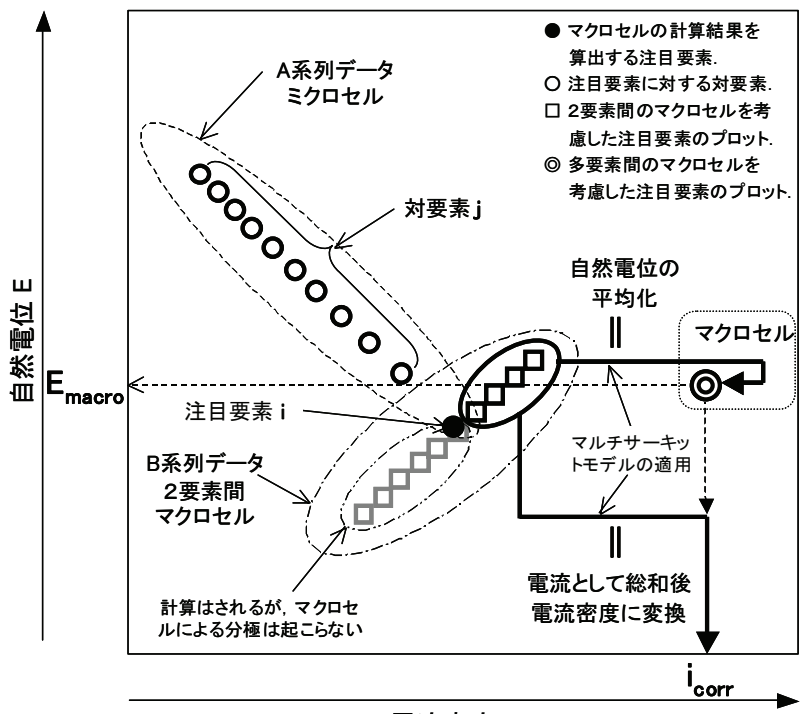

電流密度 $\log I$

図-6 マクロセルとミクロセルにおける自然電位と 電流密度との関係のモデル図

することは原理上ありえないことから，計算上小さく なる場合は総和に含めない.

なお，ここで自然電位法により測定される自然電位 と，マクロセル腐食モデルおよびマルチサーキットモ デルで計算される自然電位との関係について考察を加 える．自然電位法で測定を行うときに測定される自然 電位は，本解析手法ではマルチサーキットモデル適用 後の自然電位に相当する。したがって，この測定され る自然電位を用いて電流密度を計算するために，図-5 に示したように自然電位の差とコンクリートの見掛け の抵抗からオームの法則で導くことはできない 12)。つ まり， 2 要素間について測定される自然電位から求め られる電流密度は, 図-4に示した電流密度 $\mathrm{i}_{\text {corr }}$ ではな く，また,各要素の自然電位も図-4に示した自然電位 でもない. 
表-1 コンクリートの配合および材料

\begin{tabular}{|c|c|c|c|c|c|c|c|c|c|}
\hline \multirow[b]{2}{*}{$\begin{array}{l}\mathrm{G}_{\max } \\
\mathrm{mm}\end{array}$} & \multirow{2}{*}{$\begin{array}{l}\text { スラ } \\
\text { ンプ } \\
\mathrm{cm}\end{array}$} & \multirow[b]{2}{*}{$\begin{array}{c}\text { 空気量 } \\
\%\end{array}$} & \multirow{2}{*}{$\begin{array}{c}\mathrm{W} / \mathrm{C} \\
\%\end{array}$} & \multirow[b]{2}{*}{$\begin{array}{c}\mathrm{s} / \mathrm{a} \\
\%\end{array}$} & \multicolumn{5}{|c|}{ 単位量 $\left(\mathrm{kg} / \mathrm{m}^{3}\right)$} \\
\hline & & & & & 水 & セメント & 細骨材 & 粗骨材 & 混和剂 \\
\hline 20 & 10 & 4. 5 & 60 & 46. 1 & 162 & 270 & 858 & 1011 & 0.68 \\
\hline \multicolumn{10}{|c|}{ 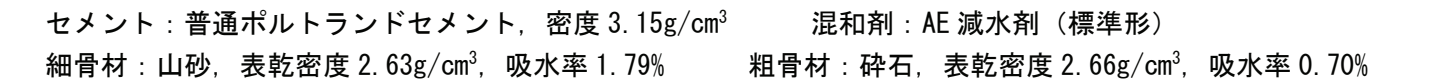 } \\
\hline
\end{tabular}

\section{（5）自然電位から電流密度への計算方法}

自然電位の分布の測定值から鋼材の腐食量の分布 を算定するために，まず自然電位から腐食電流密度 を求めることが必要である。

腐食電流密度の算出は, 電気的に連続した鋼材の 電位分布から求められる電位差により電流回路が形 成されるマクロセル腐食を想定して, 以下のような 考え方に基づき, 注目要素 $\mathrm{i}$ における電流密度を式 (3)により計算した 13),14).

つまり，まず第一に，ある時点における注目要素 $\mathrm{i}$ と対要素 j との間に構成されるマクロセル回路の 電流密度を, これら 2 要素間の電位差, 回路の見掛 けの比抵抗および要素間距離によって決定し, 第二

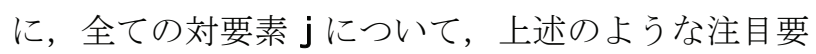
素 i との 2 要素で構成される回路を想定することに よって, 個々の回路の電流密度をそれぞれ計算し, その総和を注目要素 $\mathrm{i}$ に流入あるいは流出する電流 密度とする。

$$
\begin{aligned}
& I_{\text {corr }}=\frac{1}{B \Delta L_{i}} \sum_{j=1}^{n} \frac{\delta E_{i, j}}{w \delta L_{i, j}} B \Delta L_{j} \\
& \text { ここに， } I_{\text {corr }} \text { : i 要素の電流密度 }\left(\mathrm{A} / \mathrm{cm}^{2}\right) \\
& (\Omega \mathrm{cm}) \\
& B \text { : 要素の長さ }(\mathrm{cm}) \\
& \Delta L_{i}: \text { i 要素の幅 }(\mathrm{cm}) \\
& \Delta L_{j}: \mathrm{j} \text { 要素の幅 }(\mathrm{cm})
\end{aligned}
$$$$
\delta E_{i, j}: \mathrm{i} \text { 要素と } \mathrm{j} \text { 要素との電位差 }(\mathrm{V})
$$$$
\delta L_{i . j}: \mathrm{i} \text { 要素と } \mathrm{j} \text { 要素との距離 }(\mathrm{cm})
$$$$
w \text { : コンクリートの見掛けの比抵抗 }
$$

\section{（6）電流密度から腐食量への計算方法}

注目要素 $\mathrm{i}$ の腐食量 $m$ は電流密度 $I_{\text {corr }}$ を用いて式 (4)に示すファラデーの法則から求める.

$$
m=\frac{I_{c o r r} \cdot t \cdot a}{n \cdot F}
$$

ここに, $m$ :腐食量 $\left(\mathrm{g} / \mathrm{cm}^{2}\right), I_{c o r r}$ : 腐食電流密度 $\left(\mathrm{A} / \mathrm{cm}^{2}\right)$, $t$ : 時間 $(\mathrm{s}), a$ : 鉄の原子量 $(55.845 \mathrm{~g}), n$ : 溶解し た鉄イオンの当量 $(\mathrm{mol} \mathrm{eq}), F$ : ファラデー定数,

(96500C/mol eq）である.

\section{3 . 腐食モデルの検証と定式化に関する実験}

本章では，ミクロセル腐食モデルとマクロセル腐 食モデルを定式化し，コンクリート中の鋼材の腐食 速度を定量化することを目的に行った実験について， 供試体の作製条件と腐食を進行させるために行った 暴露実験の詳細を述べる。

\section{（1）供試体の形状，鋼材の配置およびコンクリート の配合}

供試体の形状と寸法を図-7 に示す。断面は $100 \times$ $100 \mathrm{~mm}$ ，長さは $1200 \mathrm{~mm}$ とし，供試体の内部には D13（SD295A）をかぶりを 20mm にして断面中央部 に埋め込んだ。供試体の長さを $1200 \mathrm{~mm}$ とした理由 は，マクロセル回路の形成による鋼材の腐食現象を 再現するためである。また，塩化物イオンなどの劣 化因子の移動を一次元方向とするために $100 \times$ $1200 \mathrm{~mm}$ の側部 2 面と $100 \times 100 \mathrm{~mm}$ の端部 2 面をア クリル樹脂で被覆し，鉄筋端部の腐食を抑制するた めに暴露面の両端部の $200 \mathrm{~mm}$ を同様に被覆した。 なお，供試体にコンクリートを打設した方向は長軸 方向であり，向い合った $2 つ の$ 暴露面は打設時の型 枠面に相当し同等の品質である.

コンクリートは表-1 に示すように, 水セメント比 が 60\%で, 粗骨材の最大寸法を $20 \mathrm{~mm}$, スランプ $10 \mathrm{~cm}$ の $\mathrm{AE}$ コンクリートである。かぶりが $20 \mathrm{~mm}$ に対し 粗骨材の最大寸法も $20 \mathrm{~mm}$ であることは塩化物イ才 ンの浸透などに骨材界面の影響が及ぶことが予想さ れる。ここでは塩化物イオンなどの腐食因子の移動 速度ではなく, 鋼材位置におけるそれらの濃度が重 要であることからこれを無視した。なお，養生は 28 日間以上, $20^{\circ} \mathrm{C}$ で水中養生を行った. アクリル樹脂 による被覆はこの間に行ったものである.

\section{（2）供試体の暴露条件}

供試体の環境は室内と海洋環境の 2 箇所とした。 室内環境では乾湿繰返し条件を制御することとし, $20^{\circ} \mathrm{C}$ 塩化ナトリウム濃度 $3 \%$ 水溶液に 3 日浸せきと $20^{\circ} \mathrm{C} 65 \% \mathrm{RH}$ の乾燥環境に 4 日放置を 1 サイクルとす る乾湿繰返しとした。海洋環境は写真-1 に示すよう 


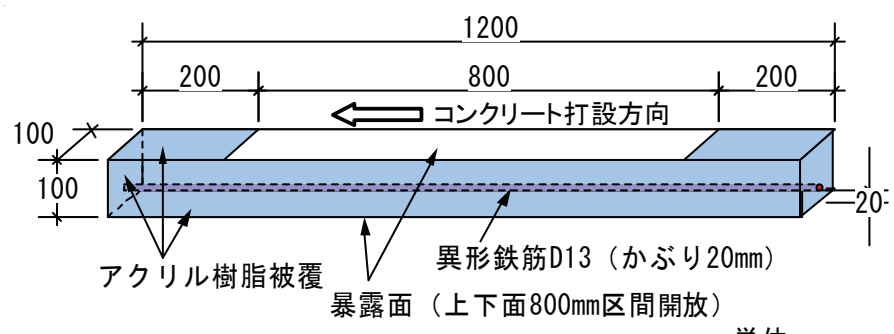

単位：mm

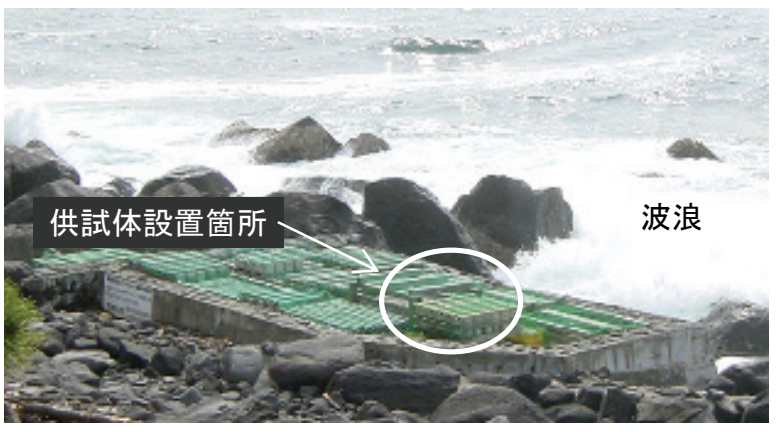

写真-1＼cjkstart暴露環境（伊豆海洋公園内）
な実海洋環境である。暴露地点は波浪による飛沫が 頻繁に作用し, 海水の作用や降雨などの天候の影響 によって乾燥と湿潤が繰り返される環境である。な お，図-7 のように暴露面は無被覆の上下方向とし， かぶり $20 \mathrm{~mm}$ の面を下向きに暴露した.

\section{（3）試験測定項目およびその方法}

暴露した供試体の変状を確認するために, 目視観 察による腐食ひび割れの確認（位置と幅）と自然電 位の測定を定期的に行った。また，腐食ひび割れが 進行し, 自然電位が-700mV（vs.CSE）程度に低下 した時点を目安に供試体を解体し，内部の鉄筋の腐 食量, コンクリート中の塩化物イオン濃度分布およ び中性化深さを測定した.

\section{a）腐食ひび割れの観察}

腐食ひび割れの発生状況の確認は, 室内環境暴露 供試体では 1 ケ月から 3 ケ月に 1 回行い, 海洋環境 暴露供試体ではおよそ 6 ケ月に 1 回の頻度で行った. 腐食ひび割れの確認は目視により行い，発生が確認 された場合にはその位置を図面に記録し，クラック スケールを用いてひび割れ幅を測定した．測定のた びにひび割れの進展を確認し，ひび割れ幅について は同じ箇所で測定した。

\section{b）自然電位の測定}

自然電位の測定方法を図-8に示す。測定は，リー ド線を介して電位差計のプラス端子とコンクリート 内部の鉄筋の一端を接続し, マイナス端子にリード 線を介して照合電極を接続して行った．照合電極は かぶり $20 \mathrm{~mm}$ 側の鉄筋直上におけるコンクリート表 面に接触させた。 室内環境暴露供試体では, 測定面 が湿潤状態にある湿潤サイクル終了時に自然電位を 測定した。また, 海洋環境暴露供試体では, 測定面 を水道水で湿潤状態にし, 電位が安定した時点で電 位差計の值を読み取った。照合電極には鉛照合電極 を使用し，コンクリート面と接触する先端にはスポ ンジを装着し, それに飽和水酸化カルシウム溶液を しみ込ませた。かぶり $20 \mathrm{~mm}$ 側の表面被覆をしてい ない $100 \times 800 \mathrm{~mm}$ の暴露面で，この範囲の鉄筋直上

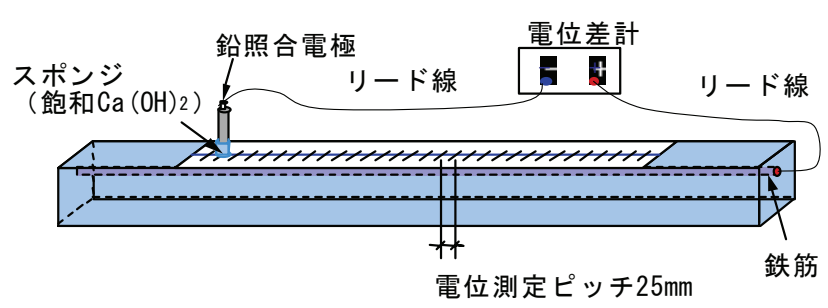

図-8 自然電位の測定方法

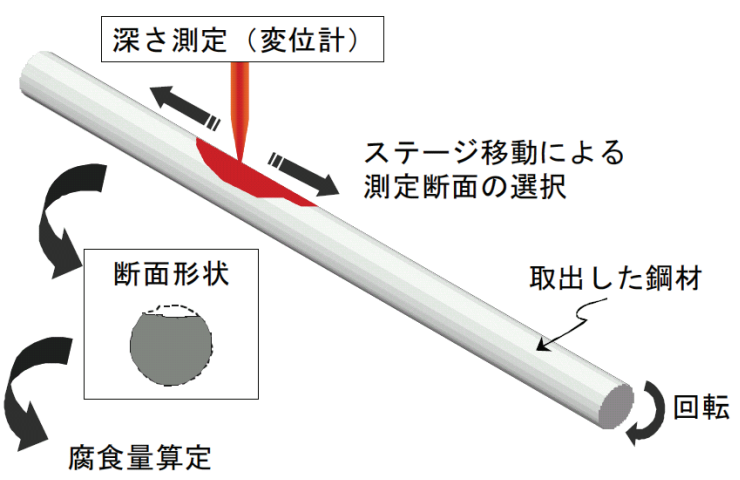

前処理 : $10 \%$ クンン酸ニアンモニウム溶液 $/ 60^{\circ} \mathrm{C} / 7.5$ 時間

図-9 鋼材の断面形状の測定方法

を $25 \mathrm{~mm}$ 間隔で照合電極を移動させて自然電位を測 定した.

\section{c）鋼材の腐食量の測定}

所定の材齢で供試体を解体して取り出した鉄筋 は, JCI-SC1「コンクリート中の鋼材の腐食評価方法」 にほぼ準拠するように，10\%クエン酸二アンモニウ ム溶液（液温 $60^{\circ} \mathrm{C}$ ）に 7.5 時間浸せきして腐食生成 物を除去した. 図-9 亿腐食生成物を除去した鉄筋の 断面形状の測定方法を示す. 図-10および写真-2 は それぞれ装置のイメージ図と写真である。断面形状 は変位計を用いて鉄筋を回転させながら半径方向の 距離を測定して記録した。一箇所の測定断面を 36 分割し, 鉄筋を 10 度ごとに回転させて測定した。測 定断面は鉄筋の長手方向に約 $20 \mathrm{~mm}$ 間隔とした。な お，横断，縦断方向とも腐食による断面欠損が激し い点があれば， $20 \mathrm{~mm}$ の測定間隔に拘わらずその点 
についても深さの測定を行った。この測定から得ら れた断面積を残存断面積とし, 鉄の密度と単位長さ から単位面積当たりの腐食量に換算した.

既往の研究では ${ }^{12)}$, 鋼材の腐食位置を測定して腐 食範囲の分布として整理したり，鋼材のある長さ当 たりの腐食面積率として整理することが多いが，本 研究のように腐食量の分布を測定することにより， マクロセル回路の形成にともなうアノードとカソー ドの位置の特定のみならず，アノードにおける腐食 の定量的な評価が可能になる.

\section{d）塩化物イオン濃度および中性化深さの測定}

コンクリートの腐食ひび割れの観察から，ひび割 れ発生位置とひび割れの発生していない位置につい て塩化物イオン濃度を測定した。これは，表面状態 が塩化物イオンの浸透方向における分布の違いに及 ぼす影響を明らかにするためである。測定は，JIS A 1154「硬化コンクリート中に含まれる塩化物イオン の試験方法」にほぼ準拠するように行った。 また, 中 性化深さはフェノールフタレインを用いて測定した.

\section{4. ミクロセル腐食モデルの定式化}

本章では, 既往の研究によりミクロセル腐食モデ ルを構成するアノード分極曲線とカソード分極曲線 を定式化する．また，鋼材の不動態被膜が破壊され るときに示寸自然電位に関しても塩化物イオン濃度 と水酸化物イオン濃度の関数として定式化する.

\section{（1）ミクロセル腐食モデルの定式化の基本的考え方}

カソード分極曲線とアノード分極曲線を定式化 するために, 図-3にその概念を示したミクロセル腐 食モデルに基づき作成した図-11 を用いて，ミクロ セル腐食モデルの定式化の基本的考え方を述べる.

図中の破線（一 - ) で示寸ように，カソード分極 曲線は Evans のダイアグラム上で右下がりの直線 で示され, カソード反応の平衡状態を表す座標（ $i_{c 0}$, $E_{c 0}$ ) (図中の○) を通るものとする. 本研究におけ るカソード分極曲線は対数目盛で傾きを一定として, 酸素の供給量が少なくなるとある電流密度よりは大 きな值にはならなくなる。これは一般に, 酸素限界 電流密度 $\mathbf{i}_{1 \text { im }}$ と言われている值である。 ここで, 傾 きをもつ直線部分のカソード分極曲線は，それが平 衡状態を示寸座標 $\left(i_{c o}, E_{c o}\right)$ と直線の傾き $\beta_{m i, c}$ を与 えることによって定式化することができる.

アノード分極曲線は, 電流密度が $\mathrm{i}_{\text {pass }}$ 上の直線と, 孔食発生の座標 $\left(i_{\text {pass }}, E_{p i t}\right)$ （図中のO印）から右上 がりの方向の直線で示される。したがって，アノー ド分極曲線は, 孔食発生の座標（ $\left.i_{\text {pass }}, E_{p i t}\right)$ と直線

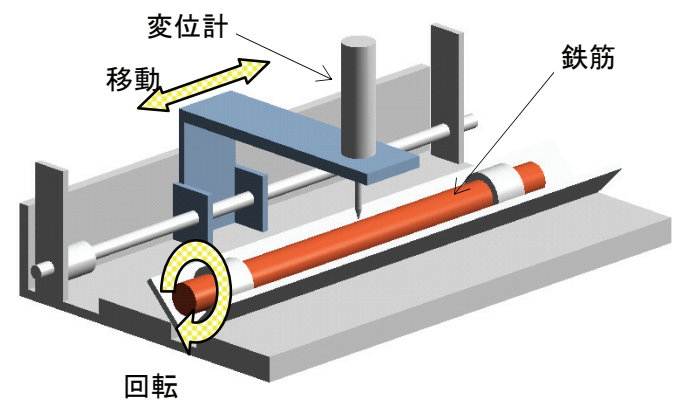

図-10 鋼材の断面形状の測定装置イメージ図

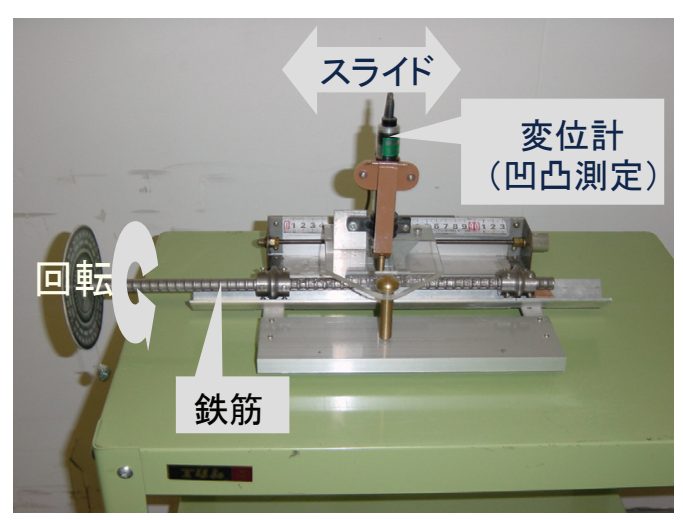

写真-2 鋼材の断面形状の測定装置

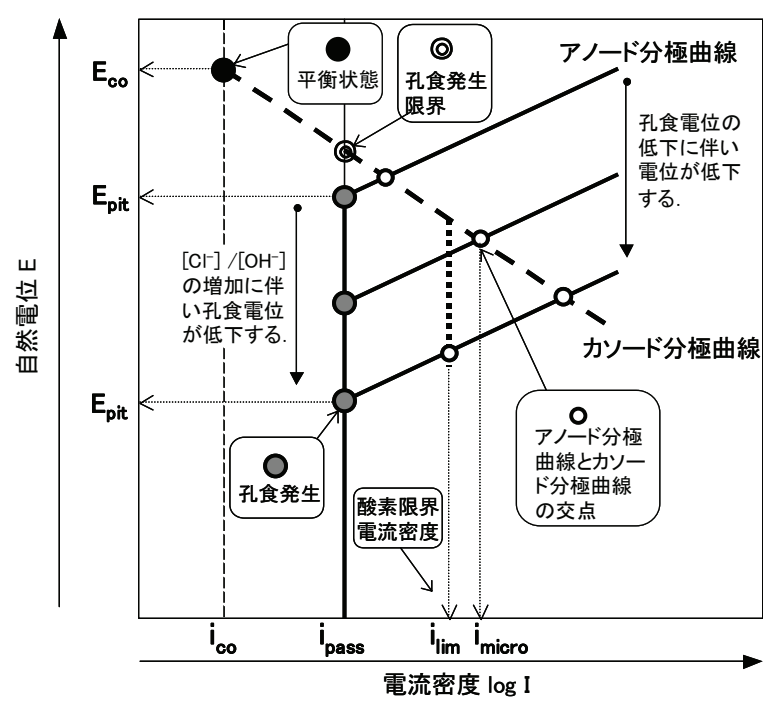

図-11 ミクロセル腐食モデルの定式化

の傾き $\beta_{\mathrm{mi}, \mathrm{a}}$ を与えることによって定式化することが できる。ここで, 不動態電流密度 $\mathrm{i}_{\text {pass }}$ は一定の值で あるが，孔食発生電位 $\mathrm{E}_{\mathrm{pit}}$ は鋼材位置におけるコン クリート中の液相の塩化物イオン濃度と水酸化物イ オン濃度比 $\left([\mathrm{Cl}] /\left[\mathrm{OH}^{-}\right]\right)$の関数とする.

以上に基づき，アノード分極曲線とカソード分極 曲線を鉄筋位置における塩化物イオン濃度や酸素の 供給量に応じて適切に設定し，それらの交点（図中 の○）の座標を求めることによって，ミクロセル腐 食モデルによる自然電位と電流密度が計算される。 


\section{（2）アノード分極曲線とカソード分極曲線}

本節では，ミクロセル腐食モデルを構成するアノ 一ド分極曲線およびカソード分極曲線について，基 本的には既往の研究におけるターフェル勾配と, 電 流密度と自然電位で与えられる座標を定めることに より定式化し, 孔食電位や限界電流密度などについ ても定式化した.

\section{a）アノード分極曲線}

アノード分極曲線は式 (5) に示すように定式化さ れる ${ }^{15), 16)}$. 自然電位が孔食電位よりも大きいときは 不動態被膜が存在しない状態であり, 自然電位の増 加とともに電流密度も大きくなる。一方, 自然電位 が孔食電位以下の場合には, 自然電位の大きさに拘 わらず電流密度は不動態電流密度 $\mathrm{i}_{\text {pass }}$ の值で一定值 となる.

$$
\begin{aligned}
& E_{\text {micro }} \geq E_{\text {pit }}(\text { 不動態被膜が存在しない }) \\
& E_{\text {micro }}=0.06 \times\left(\log \left(i_{\text {micro }}\right)-\log \left(i_{\text {pass }}\right)\right)+E_{\text {pit }} \\
& i_{\text {pass }}=5.8 \times 10^{-8} \\
& E_{\text {micro }} \leq E_{\text {pit }}(\text { 不動態被膜が存在する }) \\
& i_{\text {pass }}=5.8 \times 10^{-8} \\
& \text { ここに, } E_{\text {micro }} \text { : 自然電位 }(\mathrm{V}) \\
& E_{\text {pit }} \text { : 孔食電位 }(\mathrm{V}) \\
& i_{\text {micro }} \text { : 電流密度 }\left(\mathrm{A} / \mathrm{cm}^{2}\right) \\
& i_{\text {pass }} \quad \text { : 不動態電流密度 }\left(\mathrm{A} / \mathrm{cm}^{2}\right)
\end{aligned}
$$

\section{b）孔食発生電位}

孔食電位は式(6)に示すように定式化される ${ }^{15)}$. この式から，孔食電位の $\left(\left[\mathrm{Cl}^{-}\right] /\left[\mathrm{OH}^{-}\right]\right)$に対する関 数形がわかるが，コンクリートの細孔溶液中の $\mathrm{OH}^{-}$ イオン濃度を適切に設定しない場合には, $\mathrm{Cl} イ$ イオ 濃度を適切に設定したとしても $E_{p i t}$ は変化すること がわかる。

$$
E_{p i t}=3.4-2.3 \times \log \left(\left[\mathrm{C}^{-}\right] /\left[\mathrm{OH}^{-}\right]\right)
$$

$$
\text { ここに, } \begin{array}{ll}
E_{p i t} & \text { : 孔食電位 }(\mathrm{V}) \\
{\left[\mathrm{C}^{-}\right]} & : \text {塩化物イオン濃度 }(\mathrm{mol} / \mathrm{l}) \\
& {\left[\mathrm{OH}^{-}\right] \quad: \text { 水酸化物イオン濃度 }(\mathrm{mol} / \mathrm{l})}
\end{array}
$$

\section{c）カソード分極曲線}

カソード分極曲線は式 (7) に示すように定式化さ れる ${ }^{14)}$.

$$
\left.\begin{array}{c}
E_{\text {micro }}=E_{c o}-0.24 \times\left(\log \left(i_{\text {micro }}\right)-\log \left(i_{c o}\right)\right) \\
i_{c o}=6.25 \times 10^{-10}
\end{array}\right\}(7)
$$

\section{d）カソード反応の平衡電位}

カソード反応の平衡電位は式(8)に示すように定 式化される15).

$$
\begin{aligned}
& E_{c o}=0.914-0.0591 \times p H+0.015 \times \log \left(p O_{2}\right) \\
& \text { ここに, } E_{c o} \quad \text { : カソード反応の平衡電位 }(\mathrm{V}) \\
& p H \quad \text { : 液相の } p H \\
& \mathrm{pO}_{2} \quad \text { : 酸素の分圧 (atm) }
\end{aligned}
$$

\section{e）限界電流密度}

図-11に示したように，カソード分極曲線は酸素 の供給量が十分であれば右下がりの直線となるが, 酸素の供給が十分でないときは，その酸素の供給量 で電流密度が決まることになる。この電流密度は限 界電流密度として式(9)で表される3)。

$$
\begin{aligned}
I_{\lim } & =\frac{D n F C_{B}}{\delta} \\
\text { ここに, } & I_{\lim } \quad: \text { 限界電流密度 }\left(\mathrm{A} / \mathrm{cm}^{2}\right) \\
D & : \text { 酸素の拡散係数 }\left(1 \times 10^{-5} \mathrm{~cm}^{2} / \mathrm{s}\right) \\
n & : \text { 化学当量 }\left(\mathrm{O}_{2} \text { では } 4\right) \\
F & : \text { ファラデー定数 }(96500 \mathrm{c} / \mathrm{eq} .) \\
C_{B} & : \text { 溶存酸素濃度 }(\mathrm{mol} / \mathrm{l}) \\
\delta & \text { : 鉄筋表面の酸素拡散層 }(0.05 \mathrm{~cm})
\end{aligned}
$$

この式に上に示した定数をそれぞれ代入するこ とにより 14)，式(10)を得ることができる.

$$
I_{\lim }=\frac{M}{2.591 \times 10^{-6}}
$$

$$
\begin{array}{cc}
\text { ここに, } \quad I_{\lim } & : \text { 限界電流密度 }\left(\mathrm{A} / \mathrm{cm}^{2}\right) \\
M & : \text { 鋼材の表面における酸素分子 } \\
& \text { の流束 }\left(\mathrm{mol} / \mathrm{s} / \mathrm{cm}^{2}\right)
\end{array}
$$

なお，5章以下で行う解析においては，カソード 反応が限界電流密度で決まる場合はない。本論文で 解析する乾湿繰返しでは, 乾燥条件では限界電流密 度が十分に大きくなり，また，湿潤の場合は酸素の 供給量がきわめて少ないために不動態電流密度で決 まるからである.

\section{5. マクロセル腐食モデルの実験結果への適用 と解析手法の妥当性の検証}

本章では，ミクロセル腐食モデルから計算される 自然電位をマクロセル腐食モデルに適用して, マル チサーキットモデルからマクロセル回路形成後の自 然電位と電流密度を算出し, ファラデーの法則から 腐食量を求める。これらの值を実験結果と比較する ことにより, 本研究の解析手法の妥当性を検証する. 


\section{G-5 室内環境暴露}
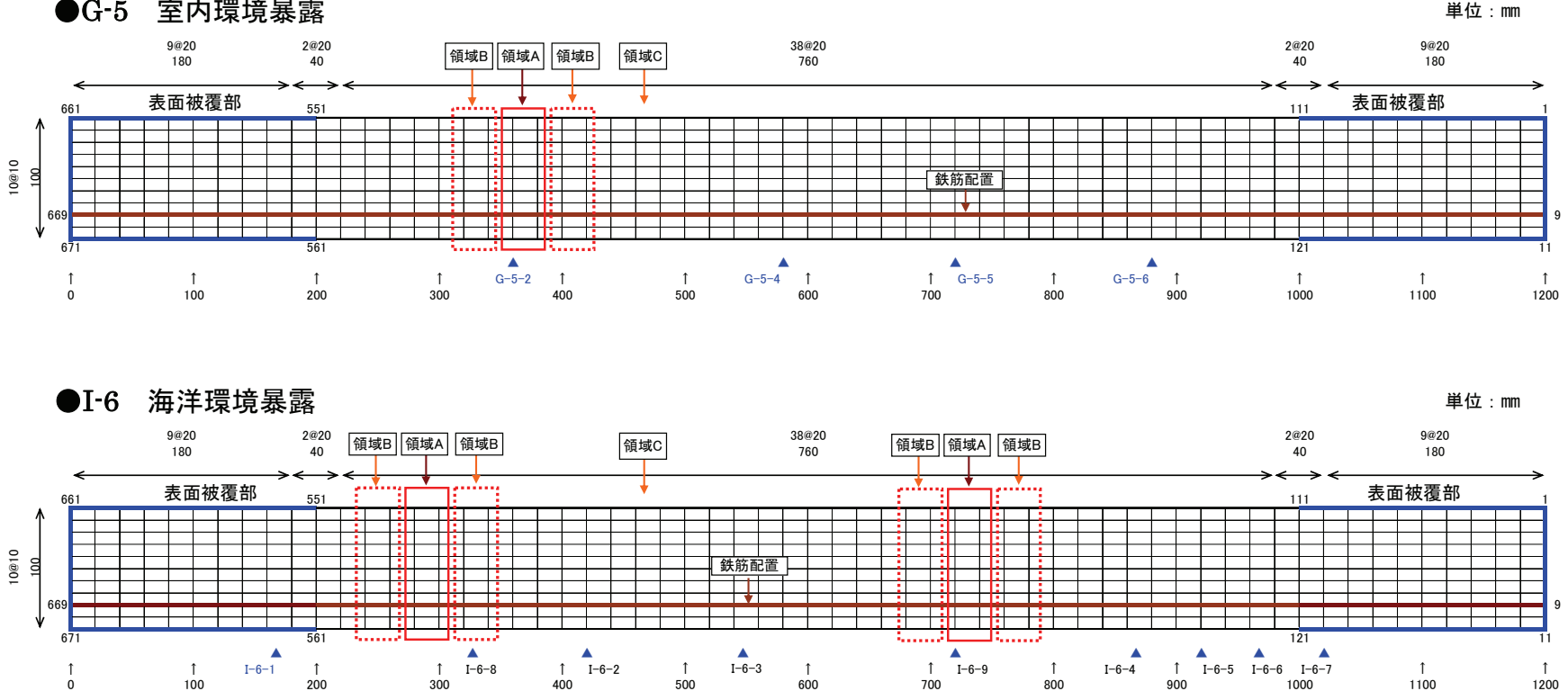

* 領域 $A$ および領域 $B$ は解析において拡散係数を別途設定した部分であり，実験の供試体では腐食ひび割れが発生した部分に相当する. 領域 A, B 以外の領域を一般部 C とする

ムは塩化物イオンの測定位置を表す．図-13 および図-14における記号と一致している

図-12 解析における供試体の要素分割

\section{（1）解析における供試体の要素分割と諸定数}

\section{a）供試体の要素分割}

コンクリート中の物質移動およびマクロセル腐食 モデルの計算は，図-7 に示す供試体を図-12 に示す ように要素分割をした解析モデルによった.これは, 供試体の縦断面を鉛直方向については $10 \mathrm{~mm}$ 間隔で, 水平方向に関しては $20 \mathrm{~mm}$ で要素分割したものであ り, 計算は二次元の有限要素法によった. 塩化物イ オンなど鋼材の腐食因子の移動は表面被覆状態など によりその方向が変化するため, 供試体の中間部 (開 放面に表面被覆を施していない部分）ではほぼ鉛直 方向となるが, 供試体端部（開放面に表面被覆を施 している部分）やひび割れ部分では水平方向の移動 も起こるため二次元での計算が必要となる.また, マクロセル腐食の計算は水平方向に配置された鉄筋 について行うものであり, 水平方向のみの一次元の 計算になるが，供試体内部の自然電位の面分布を計 算する際には二次元の計算が必要となる. 本研究で は物質移動とマクロセル腐食回路の形成の方向が異 なることから二次元の計算を行った.

\section{b）解析における諸定数}

解析における諸定数を表-2に示す，なお，本論文 の主題である腐食モデルの検証には直接関係がない 物質移動に関わる定数などは省略した. 敢えて言え ば，鋼材の腐食因子は腐食モデルの入力条件として 適切な值が設定されればよく, その入力値は物質移 動モデルで与えられようと実験值として与えられよ うと，本論文の範囲内では関係がないからである。
表-2 解析における諸定数

\begin{tabular}{|c|c|c|}
\hline \multicolumn{2}{|l|}{ 項 目 } & 定 数 \\
\hline コンクリートの見掛けの比抵抗 & {$[\Omega \mathrm{cm}]$} & 1800 \\
\hline 鉄の原子量 & & 55.84 \\
\hline 鉄の密度 & {$\left[\mathrm{mg} / \mathrm{cm}^{3}\right]$} & 7870 \\
\hline ファラデー定数 & {$[\mathrm{C} / \mathrm{mol} \mathrm{eq}]$} & 96500 \\
\hline 鉄筋の直径 & [cm] & 1.27 \\
\hline コンクリート中(未中性化部)の液 & & 12.4 \\
\hline 暴露期間（室内環境暴露） $\quad$ G-5 & [日] & 1575 \\
\hline （海洋環境暴露） $\quad \mathrm{I}-6$ & [日] & 1305 \\
\hline
\end{tabular}

図-4 に示寸マクロセル回路形成における分極時 の勾配（ミクロセル回路ではターフェル勾配に相当 するもの）は式(11)によった 15)。これらの勾配はコ ンクリートの細孔溶液中に存在する塩化物イオンを コンクリート単位体積当たりの質量で表した自由塩 化物量の関数である,

$$
\left.\begin{array}{r}
\beta_{\text {ma }, a}=-0.012 \times \log \left(C_{\text {free }} / 0.593\right)+0.19 \\
\beta_{\text {ma,c }}=0.037 \times \log \left(C_{\text {free }} / 0.593\right)-0.26
\end{array}\right\}
$$

\section{（2）解析と実験における塩化物イオンの移動}

塩化物イオンの移動に関して, 供試体の暴露環境 である室内環境と海洋環境に別けて述べる。供試体 


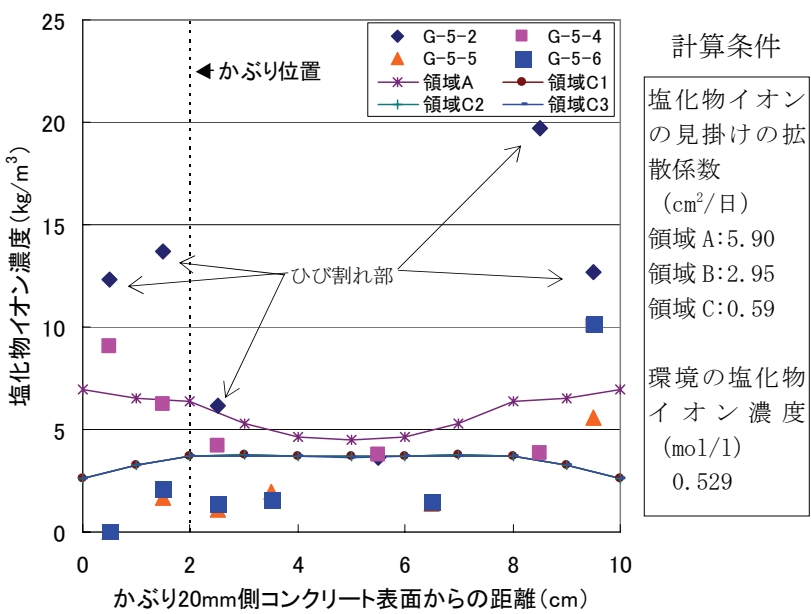

図-13 塩化物イオン濃度分布

（G-5 室内環境暴露）

記号は室内環境暴露のものを G-5, 海洋環境暴露の ものを I-6 とする. なお，ここで計算される塩化物 イオン濃度は, コンクリート単位体積当たりの塩化 物イオンの質量であるが，これを液相中の塩化物イ オンモル濃度として求めた值は, 4 章 (2)b)で述べた 孔食電位の算定 (式 (6)) に用いられる。

\section{a）室内環境（制御された乾湿繰返し環境 G-5）}

塩化物イオンの移動は，乾湿繰返しの影響を考慮 できる水分の移動解析を連成させた手法を用い 10), 鋼材位置における液相の塩化物イオン濃度を算出し た。塩化物イオン濃度の算出では, 液相の塩化物イ オン濃度勾配を駆動力とし，フリーデル氏塩などの 固定および吸着現象も考慮した。図-13 に，暴露期 間 1575 日後における塩化物イオン濃度の分布と解 析結果を示す. 図中の実線で結ばれた点は解析值で あり，その他の点は図-12（上図）に示した位置にお ける実測值である. 図-13 の計算条件に示すように, 腐食ひび割れが発生した部分の塩化物イオンの拡散 係数をそれ以外の部分よりも大きく設定した。これ は，図-13 からもわかるように腐食ひび割れ発生部 分において鉄筋位置における塩化物イオン濃度がひ び割れ発生箇所に対して相対的に高かったことによ る.しかし，このような状況は必ずしも拡散係数が 大きいことに直接起因するとは言えず，ひび割れ発 生後に塩化物イオンの移動が促進されたことによる とも十分考えられるが，ここでは鉄筋位置における 塩化物イオン濃度を大きくするために拡散係数の值 を仮定した。

\section{b）海洋環境（自然界における乾湿繰返し環境 I-6）}

図-14 に, 暴露期間 1305 日後における塩化物イオ ン濃度の分布と解析結果を示す. 図中の実線で結ば れた点は解析值であり，その他の点は図-12（下図） に示した位置における実測值である。図-14 に示す

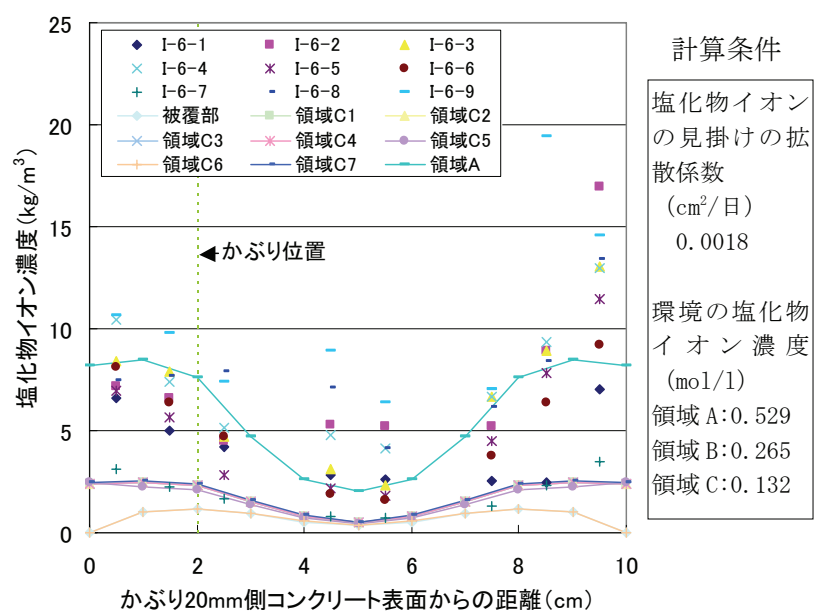

図-14 塩化物イオン濃度分布

（I-6 海洋環境暴露）

ように，腐食ひび割れが発生した部分の塩化物イオ ンの境界条件をそれ以外の部分よりも大きく設定し た。ここでの設定方法は，室内暴露試験体とは異な り外部環境の塩化物イオン濃度を変化させた。

\section{（3）腐食発生限界の塩化物イオンの濃度}

コンクリート中の鋼材の自然電位は図-15 に示寸 ような変化を示し，鉄筋の腐食が開始したと推定さ れる時点（図中の』印）以降，自然電位が急激に低 下寸るとともに測定点ごとの自然電位にばらつきが 生じる。ここでは，自然電位の変化が急激に起きる 時点を鉄筋の腐食開始時期とし，鉄筋位置における 塩化物イオン濃度を求め, 腐食発生時の $\left[\mathrm{Cl}^{-}\right] /\left[\mathrm{OH}^{-}\right]$ を計算した。

なお，ここで求める[Cl]/[OH]を式(6)に代入して 算出される $\mathrm{E}_{\mathrm{pit}}$ は, 図-11 の孔食発生限界の電位に 相当し，ミクロセル腐食モデルでは，酸素の供給が 十分に行われるとした場合のカソード分極曲線と不 動態電流密度を示寸直線の交点 (図中の@) となる. 本研究では，腐食開始時点の鋼材表面の塩化物イ オン濃度は測定しておらず，図-15 に示した暴露期 間 1575 日後における塩化物イオン濃度分布から時 間を遡って推定した值であり，また，水酸化物イオ ン濃度も表-2に示すように仮定した $\mathrm{pH}$ を用いて求 めることから，計算される[Cl- $] /\left[\mathrm{OH}^{-}\right]$は不確定要因 を含むものである．このことを前提に, $[\mathrm{Cl}-] /\left[\mathrm{OH}^{-}\right]$ を求めるとその值は 41.2 となる. 既往の研究 17)では, 腐食発生時の $\left[\mathrm{Cl}^{-}\right] /\left[\mathrm{OH}^{-}\right]$の範囲は $0.4 \sim 10.0$ の範囲で あり，本研究における值は極めて大きい值である。 しかし，[Cl-]/[OH-1は $\mathrm{pH}$ を大きく設定することに より小さくなり, $[\mathrm{Cl}] /\left[\mathrm{OH}^{-}\right]$の閾值を求めるために は鋼材の腐食が発生した時点における液相の $\mathrm{pH}$ も 測定する必要がある. 本研究では表-2に示すように 


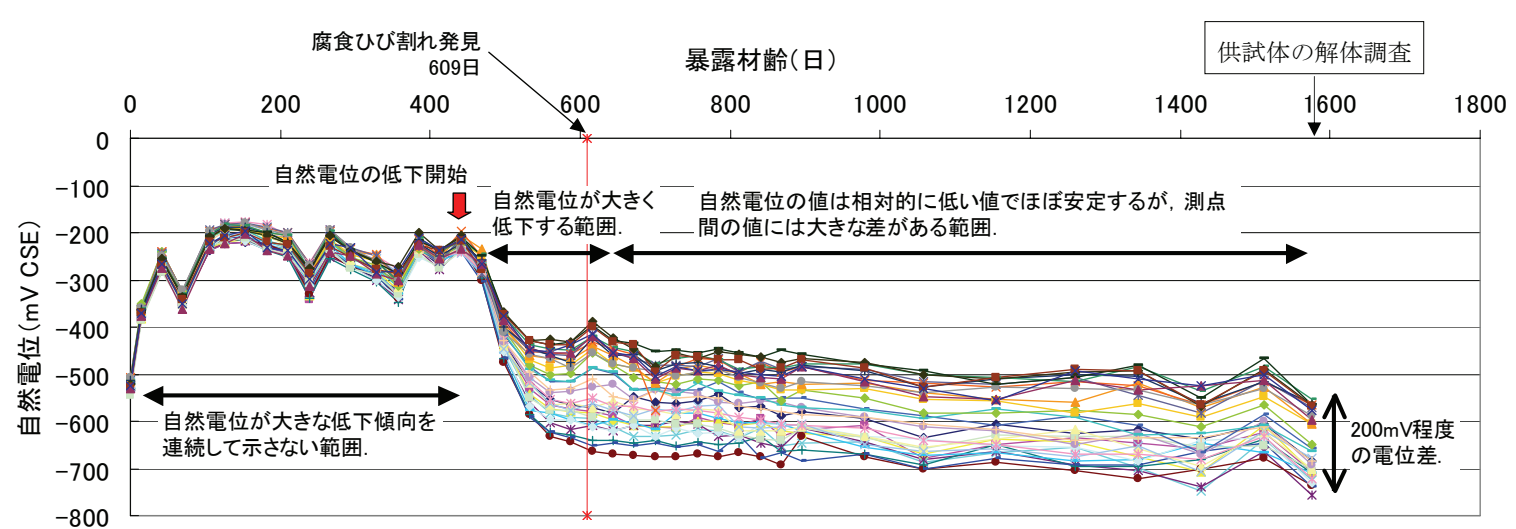

図-15 自然電位の実測值（G-5 室内環境暴露）

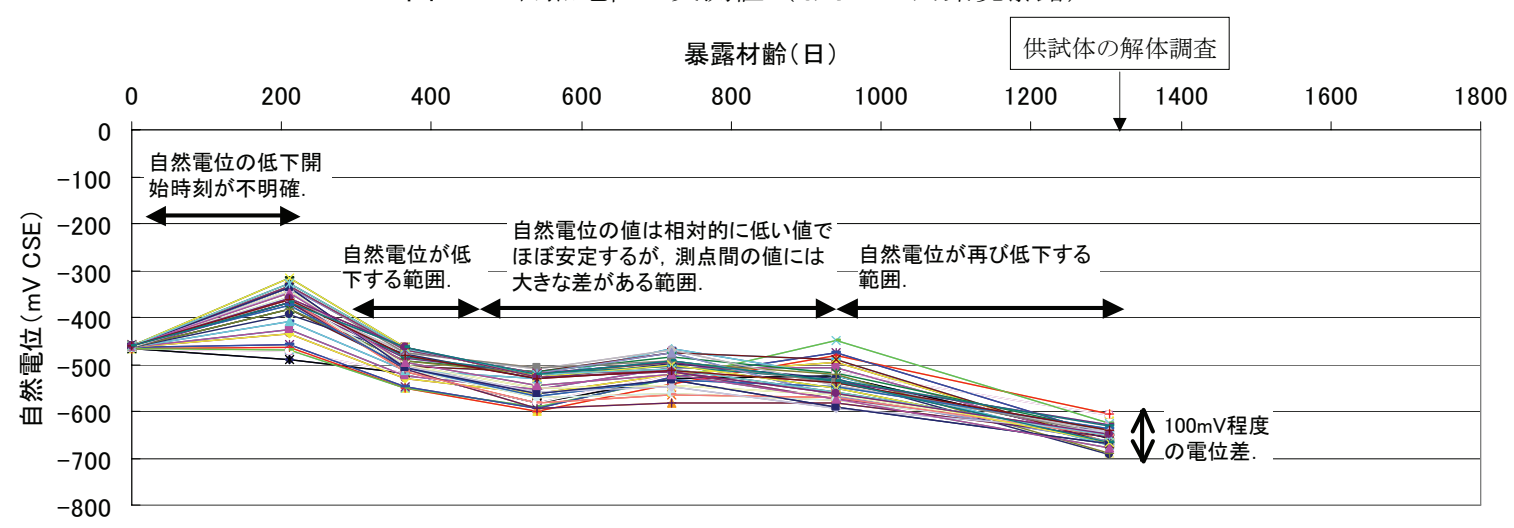

図-16 自然電位の実測值（I-6 海洋環境暴露）

$\mathrm{pH}=12.4$ を設定していることから $[\mathrm{Cl}] /\left[\mathrm{OH}^{-}\right]$の闇值 は 41.2 であるが, $\mathrm{pH}=13.4$ を仮定することによりそ の值は $1 / 10$ の 4.12 となる.ここでは, 腐食発生時 期を適切に評価できればよいことから $\left[\mathrm{Cl}^{-}\right] /\left[\mathrm{OH}^{-}\right] の$ 絶対值は問題としないが, $\mathrm{pH}$ の設定值とともに今 後定量化の検討が必要である.

\section{（4）自然電位の経時変化の傾向と暴露環境間の比較}

本節では，室内環境暴露供試体（G-5） と海洋環 境暴露供試体（I-6）の自然電位測定結果について, それぞれの暴露環境における経時変化の傾向と相互 比較に関する考察を行い, 自然電位の測定值の特徵 を抽出する.

\section{a）自然電位の実測値における経時変化の傾向}

図-15 は室内環境暴露供試体 (G-5) の自然電位の 経時変化を示したものである. 本章(3) でも既に述べ たように，暴露材齢が 450 日程度で急激に自然電位 の低下が見られる，それ以前については，暴露開始 直後から自然電位は増加し, $-350 \mathrm{mV}$ と $-200 \mathrm{mV}$ の間 を各測点間に大きな差がなく変位している.ただし， 全体としては断続的に減少と増加を繰り返している. また, 暴露材齢 600 日程度以降では, 各測点間の自 然電位の最大值と最小值の差は約 $200 \mathrm{mV}$ である.こ のように自然電位が側点間で異なる理由としては, 塩化物イオンの供給の相違によりアノード分極曲線 が変化したり, 酸素の供給の相違によりカソード分

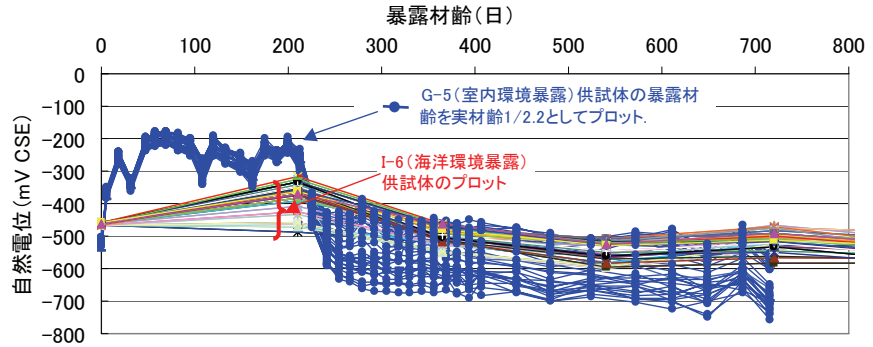

図-17暴露環境間での自然電位の相互比較

極曲線が変化することが考えられる.

図-16 は海洋環境暴露供試体（I-6）の自然電位の 経時変化を示したものであるが，室内環境暴露の場 合とは異なり, 自然電位の明確な低下時期を示して いない，ただし，暴露開始時点（暴露材齢 0 日）に おいては各測点間でほぼ同じ值であった自然電位が, 暴露材齢 200 日程度以降では各測点間に大きな差を 示しながら低下寸る傾向にある。

\section{b）暴露環境間での自然電位の相互比較}

図-17 は，室内環境暴露供試体（G-5）と海洋環境 暴露供試体（I-6）の自然電位測定結果の相互比較を 行うために, 室内環境暴露供試体（G-5）の暴露材 齢を時間軸方向に $1 / 2.2$ に圧縮したものと, 海洋環 境暴露供試体（I-6）のデータ（時間軸方向に暴露材 齢を圧縮していない）を同一の図上に示したもので ある。このような時間の圧縮を行った理由は，I-6 で自然電位が大きな変化を開始する時刻が明確に捉 

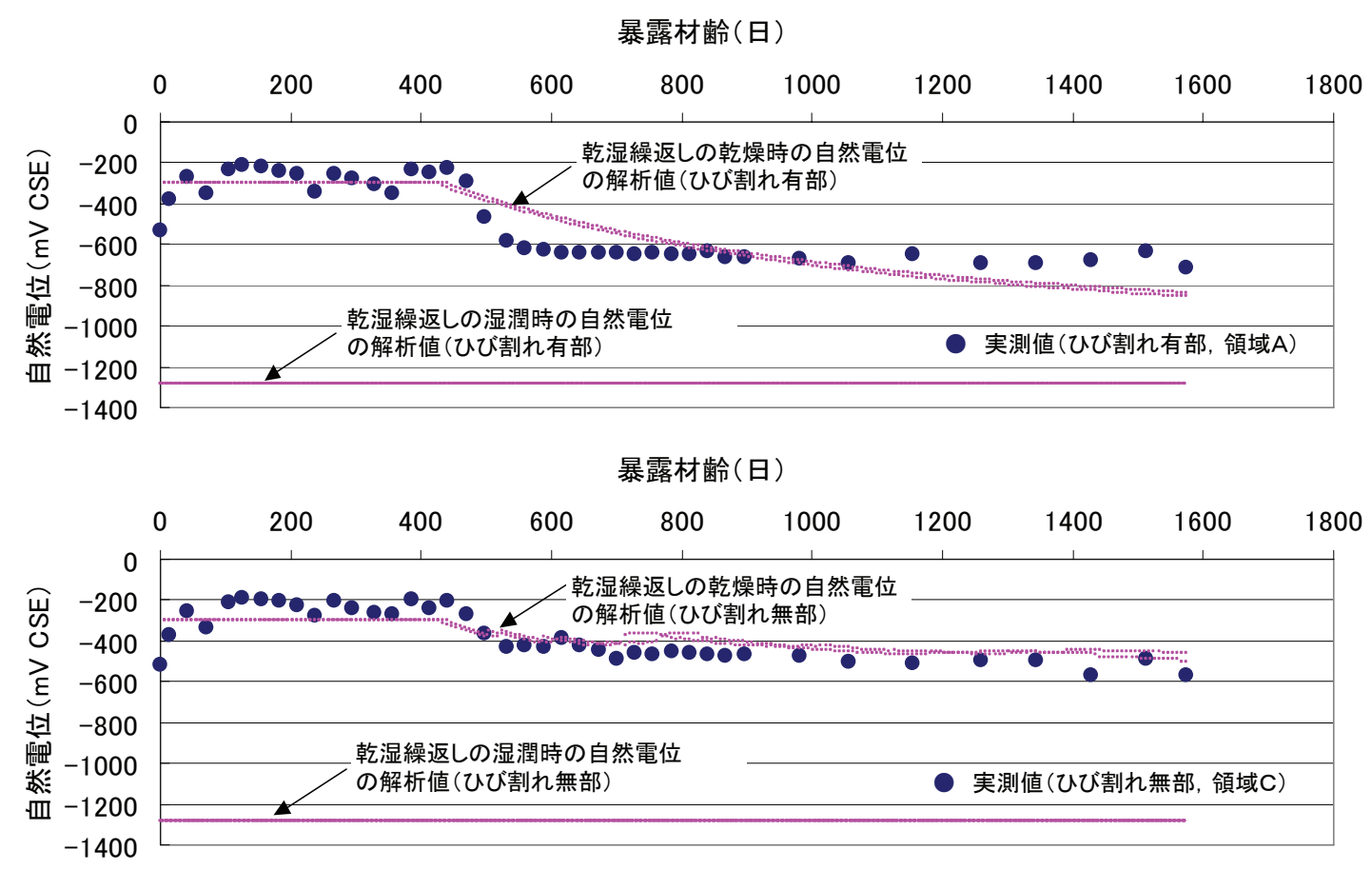

図-18 自然電位の経時変化における実験值と解析值との比較（G-5 室内環境暴露）

（上図：ひび割れがある部分，下図：ひび割れが無い部分）

えられなかった理由として, I-6では自然電位を測定 する時間間隔が長かったことから，時間間隔が短け ればそれを捉えることは可能であったと予想される こと， I-6 の方が G-5 よりも鉄筋の腐食によるひび 割れの発生時期が早かったため, 自然電位の低下時 期も I-6 の方が G-5 よりも早いと推測されることに よる.

時間軸方向の圧縮率の決定は図-17 から，I-6 では 暴露材齢 200 日程度までは G-5 を時間軸方向に圧縮 した点のような值を示していたと予測され，自然電 位の大きな変化はそれ以降に起きたものと推定され ることによった。ただし，自然電位の各測点間にお ける差ついては I-6 と G-5 で異なっているが，これ は暴露環境条件によりカソード部とアノード部の形 成に差ができることによると考えられる。

\section{（5）自然電位の実測値と解析結果の整合性の確認}

本節では，2 章，4章および5章で述べた解析手 法を室内環境暴露供試体（G-5） と海洋環境暴露供 試体（I-6）の自然電位の測定結果に適用し，実測值 と解析值の間の整合性を確認することによって解析 手法の妥当性を検証する. また，ミクロセル回路お よびマクロセル回路の解析上の電流密度に関する考 察も行う。

\section{a）室内環境暴露供試体（G-5）}

図-18 は，自然電位の実測值と解析值の経時変化 をひび割れが発生した部分と発生しなかった部分で それぞれ示したものであり, 図-19 は, 暴露材齢 1575
日における自然電位の分布を実測值と解析值で示し た図である。

図-18の上下それぞれで解析值が- $250 \mathrm{mV}$ 程度から 時間とともに低下寸る部分と $-1300 \mathrm{mV}$ 程度で一定值 を示す部分に分かれているが，本手法では，後者は 乾湿繰返しにおける湿潤時の自然電位を表している. 湿潤時には解析上酸素の供給がなくなるため, 図-11 で $\mathrm{i}_{\text {Iim }}$ の值が小さくなり, カソード分極曲線とアノ ード分極曲線の交点である自然電位も小さくなる.

図-18 から，ひび割れ有部（最も自然電位の低い 箇所）もひび割れ無部も解析值は実測值の経時変化 とよく整合しており，解析の妥当性がわかる．ただ し，ひび割れ有部では，鉄筋の腐食が開始し自然電 位が急激に低下寸る暴露材齢 500 日程度で実測值の 方が解析值よりも低下が短期間に起き，自然電位が 低下した後では，実測值はほぼ一定值を示すのに対 し, 解析値は漸減傾向を示す。この理由としては, 図-11 に示寸ミクロセルモデルで，本研究の塩化物 イオン濃度の範囲ではアノード分極曲線が塩化物イ オン濃度の増加に対して低下傾向を連続して示寸た めと考えられる.

図-19 は一見して明らかなように，自然電位の実 測值と解析值ではその分布傾向に大きな違いがある。 つまり，いずれもひび割れ部分で自然電位の值は小 さくなるが，実測值ではなだらかに自然電位が分布 しているのに対し，解析值ではひび割れ部周辺で自 然電位が顕著に低下寸る。この理由としては，図-12 に示寸解析条件で，拡散係数の值を変化させる要素 


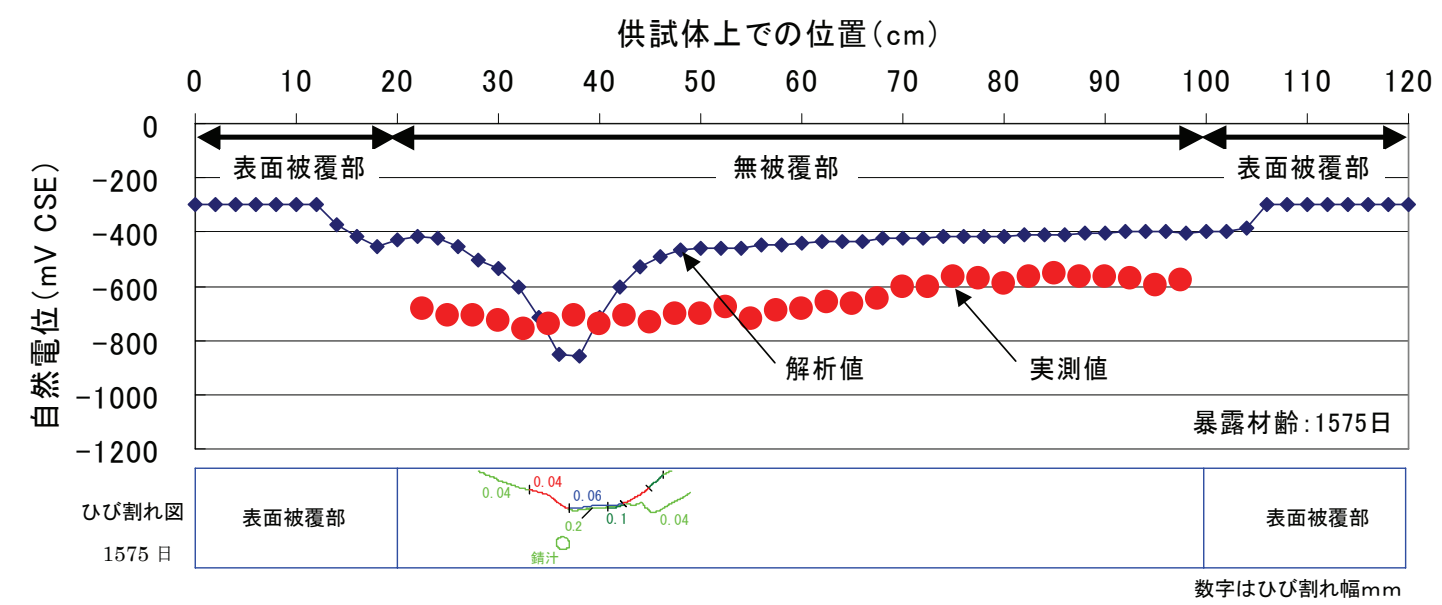

図-19 自然電位の供試体上における分布の実験值と解析值との比較（G-5 室内環境暴露）

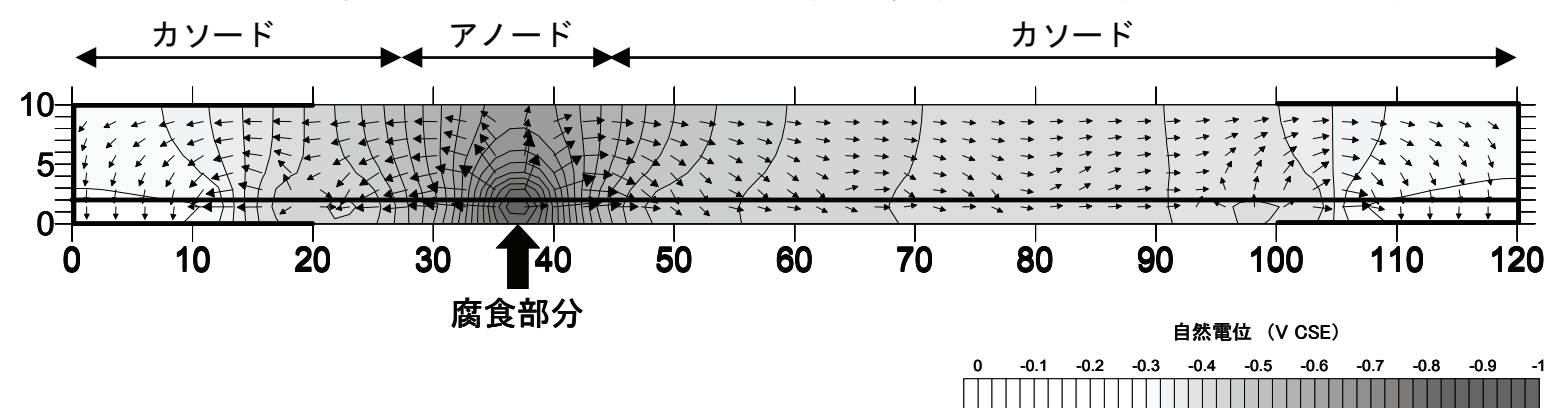

図-20 自然電位の等電位線と電流の方向 [暴露材齢 : 1575 日］（G-5 室内環境暴露）

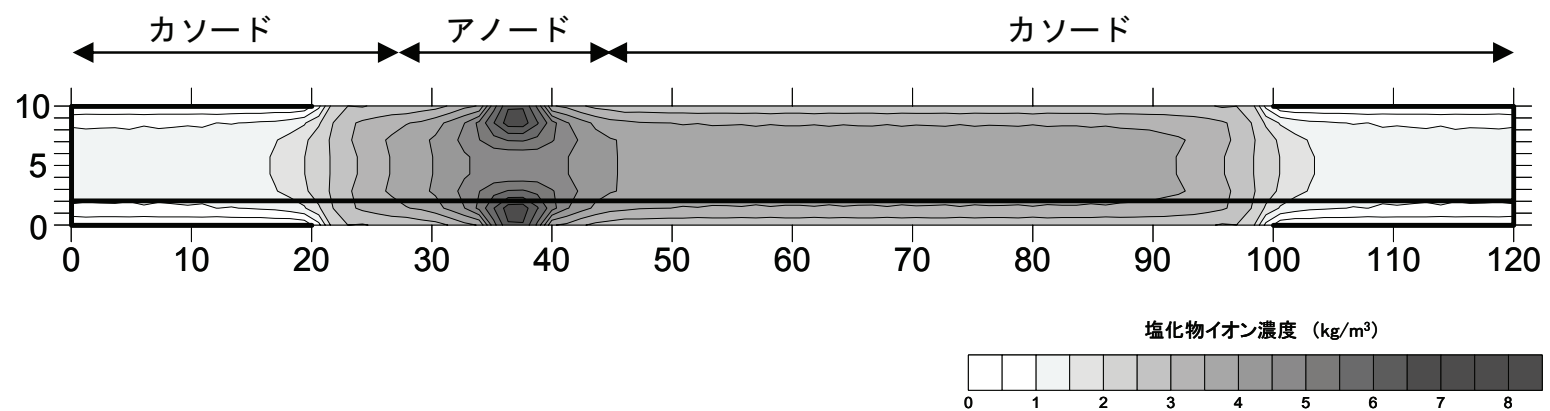

図-21＼cjkstart塩化物イオン濃度の分布状態［暴露材齢：1575日］（G-5 室内環境暴露）

である領域 Aおよび領域 Bがせまい範囲であったこ となどによると考えられる。

図-20 は自然電位の等電位線とコンクリート中の 電流の方向を示したものであり, ラプラス方程式を 鉄筋上の電位と, コンクリート表面（4辺）におけ る電流の出入がない境界条件で解いた結果である ${ }^{18)}$ この図から供試体内部の鉄筋に関してマクロセルが 形成されている状況がよくわかる. 図-21 にはこの ときの塩化物イオン濃度を示した。すなおち，腐食 部分（図中の\}）がアノードとなり，電流が流出し ている部分で塩化物イオン濃度が高いことがわかる。 なお，本研究における自然電位の測定は，鉄筋位置 ではなくコンクリート表面で行ったものであるが， 図からわかるようにかぶり $2 \mathrm{~cm}$ 程度であれば両者の 自然電位はほぼ等しいと考えられる 12 .

図-22 にはミクロセル回路とマクロセル回路にお

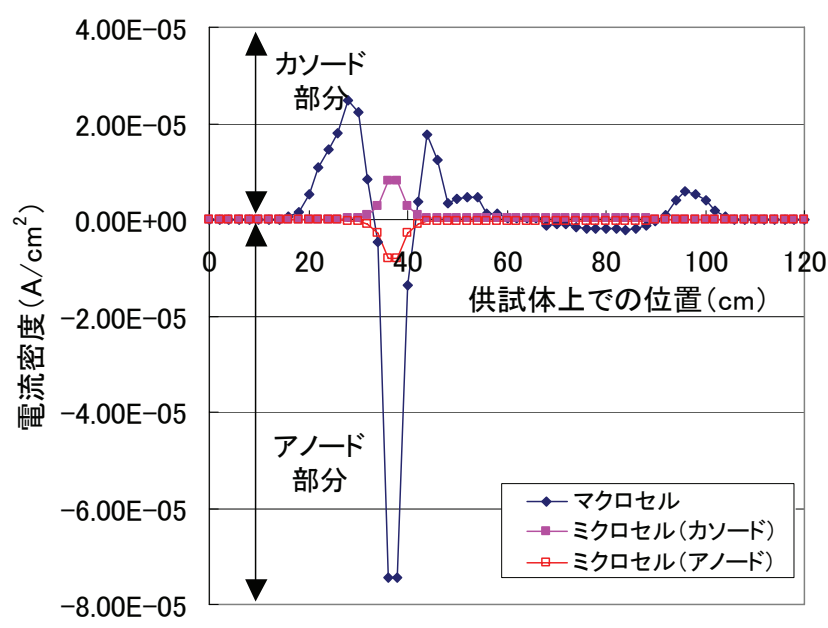

図-22 ミクロセル回路とマクロセル回路における 電流密度の比較 

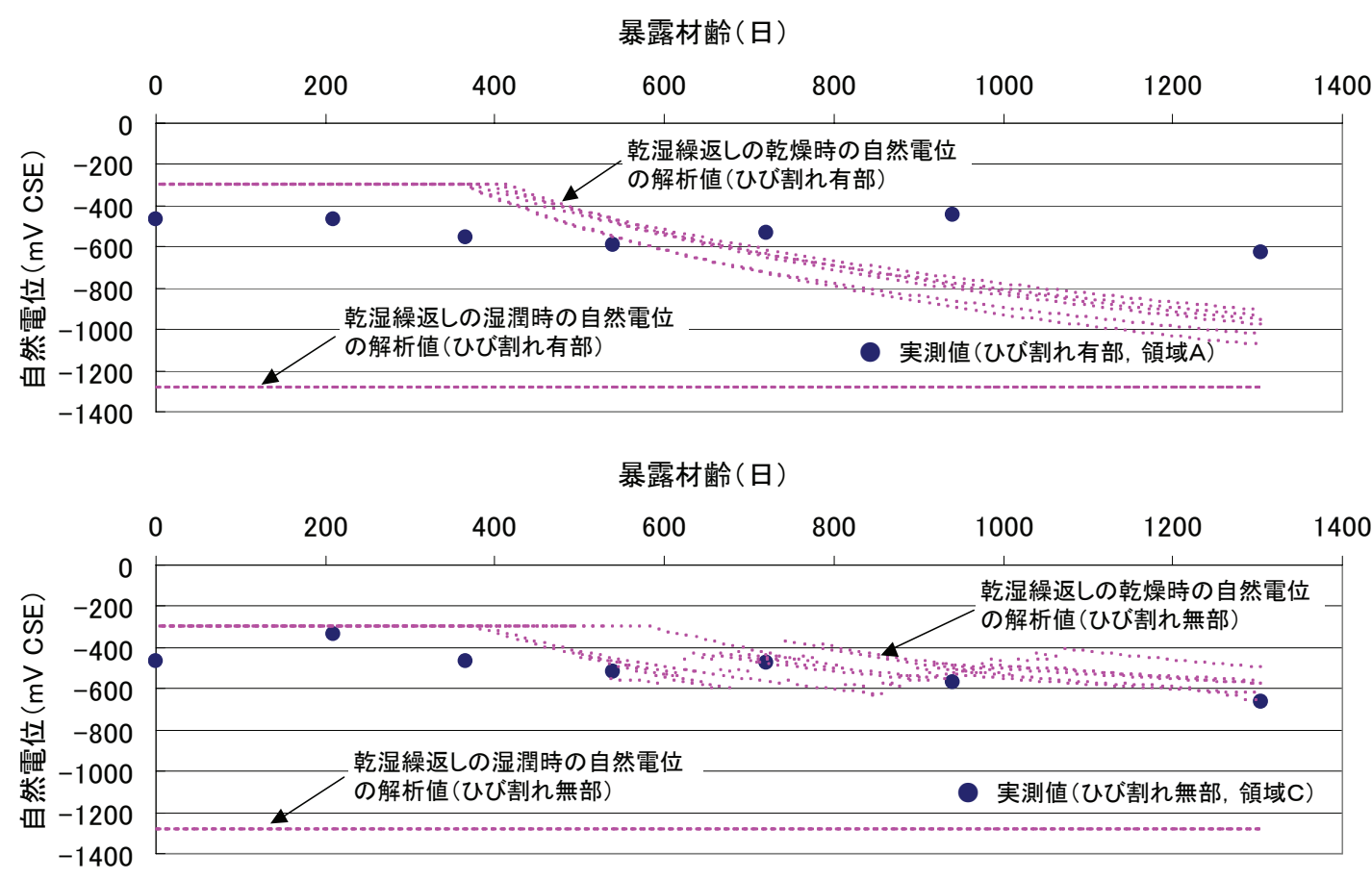

図-23 自然電位の経時変化における実験值と解析值との比較（I-6 海洋環境暴露）

（上図：ひび割れがある部分，下図：ひび割れが無い部分）

ける電流密度を示す。ミクロセル回路における電流 密度は, 正の值がカソード部分を, 負の值がアノー ド部分を示しており, 各部分でそれらの絶対值は等 しい。ママクロセル回路においては，マクロセル腐食 モデルによりアノードとなる部分が鉄筋の腐食に関 係する電流密度になる.

ミクロセル回路とマクロセル回路における電流密 度が最大となる位置, すなわちアノードの位置は一 致することがわかる。しかし, 電流密度の值は大き く異なっている. 図の縦軸である電流密度をみると, 電流密度が最も大きくなる位置においては，マクロ セル回路の電流密度はミクロセル回路の電流密度の 7 倍程度以上になる。

本研究ではマクロセル回路における腐食を対象に していることから, その回路におけるカソード部分 の電流密度は正の值となり, 腐食量の算定には寄与 しないものである。従来は，ミクロセル回路とマク ロセル回路は同時に形成されており, それぞれの電 流密度は個別に計算でき加算できると考えられてい るが5), 本研究では, マクロセル回路形成後は存在 するのはマクロセル回路による電流密度のみである と考えるため, 図-22 に示すマクロセル回路とミク ロセル回路の電流密度の差がマクロセル回路による 電流密度の増分と考えるものではない.

\section{b）海洋環境暴露供試体（I-6）}

図-23 は，自然電位の実測值と解析值の経時変化 をひび割れが発生した部分と発生しなかった部分で
それぞれ示したものであり, 図-24 は, 暴露材齢 1305 日における自然電位の分布を実測值と解析值で示し た図である.解析における乾湿繰返しの日数設定は, 塩化物イオンの移動を考慮して, 湿潤 3 日, 乾燥 8 日とした。

図-23 の上図（ひび割れがある部分）からわかる ように, 解析值と実測值はほとんど一致していない. 5 章 (4) で述べたように実測值は自然電位の経時変 化がほとんど見られないのに対し，解析值では腐食 開始時期とその後の経時変化の傾向が明瞭である.

図-23 の下図（ひび割れがない部分）では，解析值 も自然電位の変化が少ないことから実測值に合う傾 向を示してはいるが，実測值においては腐食開始時 期が明瞭ではない。なお，乾燥時の自然電位の解析 值が幅を有するのは，乾燥条件における酸素の供給 量の変化に応じてカソード分極曲線が変化するモデ ルによる，全体的な経時変化の傾向と図-17 に関し て述べた内容から考えると, 暴露材齢 200 日程度で 腐食が開始すると推定することが適当であると考え られるが, 本研究では室内環境暴露供試体の実験結 果をシミュレートするためのモデルと敢えて異なっ た考え方を行うにはデータ数も少ないことから，実 験結果に解析結果を合わせるような操作は行わない。

図-24 でも実測值と解析值の自然電位の分布傾向 は大きく異なっている. すなわち, 実測值において はひび割れがある部分もない部分も, 自然電位の值 に大きな相違は見られないが，解析值ではひび割れ 


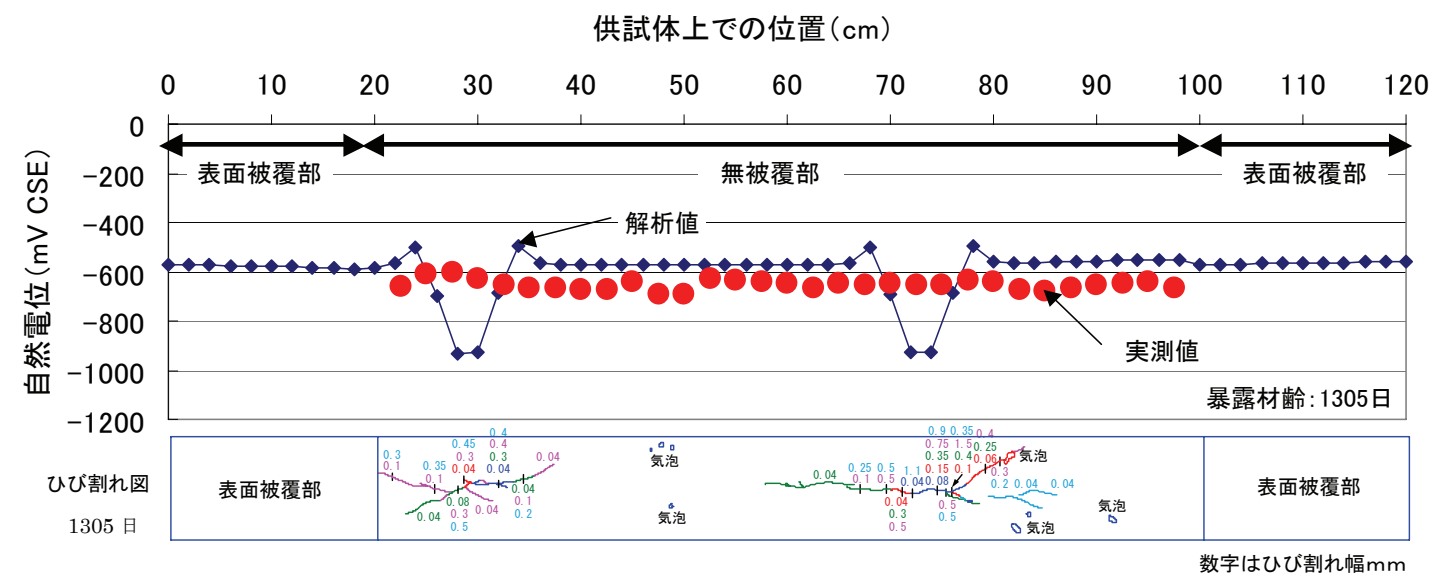

図-24 自然電位の供試体上における分布の実験值と解析值との比較（I-6 海洋環境暴露）

がある部分の自然電位が小さい值となっている。

以上より，海洋環境暴露供試体については，本論 文で示した解析手法の適用に関して検討しなければ ならない点が多いことがわかる。具体的な今後の検 討項目については本章 (6)の腐食量の考察部分で示 すこととする。

\section{（6）実験と解析における腐食量の比較}

本節では，2 章で述べた解析手法を室内環境暴露 供試体（G-5） と海洋環境暴露供試体（I-6）の鉄筋 の腐食量の測定結果に適用し，実測值と解析值の間 の整合性を考察することによって解析手法の妥当性 を検証し，あわせて解析手法全体にかかわる問題点 も抽出する。

\section{a）室内環境暴露供試体（G-5）}

室内環境暴露供試体（G-5）の鉄筋の腐食量の分 布に関する実測值と解析值を図-25 に示す。直接測 定の腐食量の值が鉄筋上のすべての位置においては 存在しないのは，鉄筋の目視観察結果では腐食が認 められず，図-10 に示した装置では測定を行わなか ったことによる. なお，測定を行っていない部分の 腐食量は 0 とした。

実測值と解析值を比較すると, 腐食量の最大值付 近では解析值の腐食量の方が小さい. 解析ではマク ロセル回路の形成が腐食量に大きな影響を及ぼすが, 実測の自然電位分布の傾向が解析でもとめた自然電 位分布の傾向とは異なっていること, 解析における コンクリートの比抵抗の設定が適切でなかったこと などが原因として考えられる。

\section{b) 海洋環境暴露供試体（I-6）}

海洋環境暴露供試体（I-6）の鉄筋の腐食量の分布 に関する実測值と解析值を図-26に示す。海洋環境 暴露供試体は腐食ひび割れが二箇所に別れて発生し
たため, 解析值の腐食量もその位置付近で大きな值 となっている。しかし，室内環境暴露供試体のよう に実測值と解析值で腐食の顕著な位置は必ずしも一 致していない。これは，塩化物イオンの拡散係数の 設定箇所と腐食が最も進行している箇所が一致して いないことによると考えられる。

\section{（7）解析手法全体に関する今後の課題}

本研究で構築した解析手法は，鉄筋表面位置にお ける塩化物イオン濃度や酸素供給量からミクロセル における自然電位と電流密度を計算し，このミクロ セルにおける自然電位差によりさらに分極が進行し て腐食電流のマクロセル回路を形成するという考え 方に基づいたものである。したがって，物質移動の 計算, ミクロセルにおける自然電位や電流密度の計 算の精度が低い場合およびマクロセル回路形成にお けるコンクリートの比抵抗の設定などが適切になさ れない場合には，マクロセル電流密度と腐食量が精 度よく計算されないことになる。とくに，ミクロセ ルにおける自然電位の推定は, アノード分極曲線, 孔食発生電位，カソード分極曲線を精度よく設定す ることが重要であり，今後これらの精度を向上させ ることや上記考え方の実験的検証が重要である.

\section{6. マクロセル回路形成の解析例}

本章では，マクロセル回路を形成する事例として 断面修復部分周辺の鉄筋とコンクリート表面からの 距離が異なる 2 段鉄筋の 2 ケースを選定し，本論文 で述べてきた鉄筋腐食の解析手法によりマクロセル 回路による腐食の増加について解析的に検討した結 果を論じる. 
供試体上での位置 $(\mathrm{cm})$

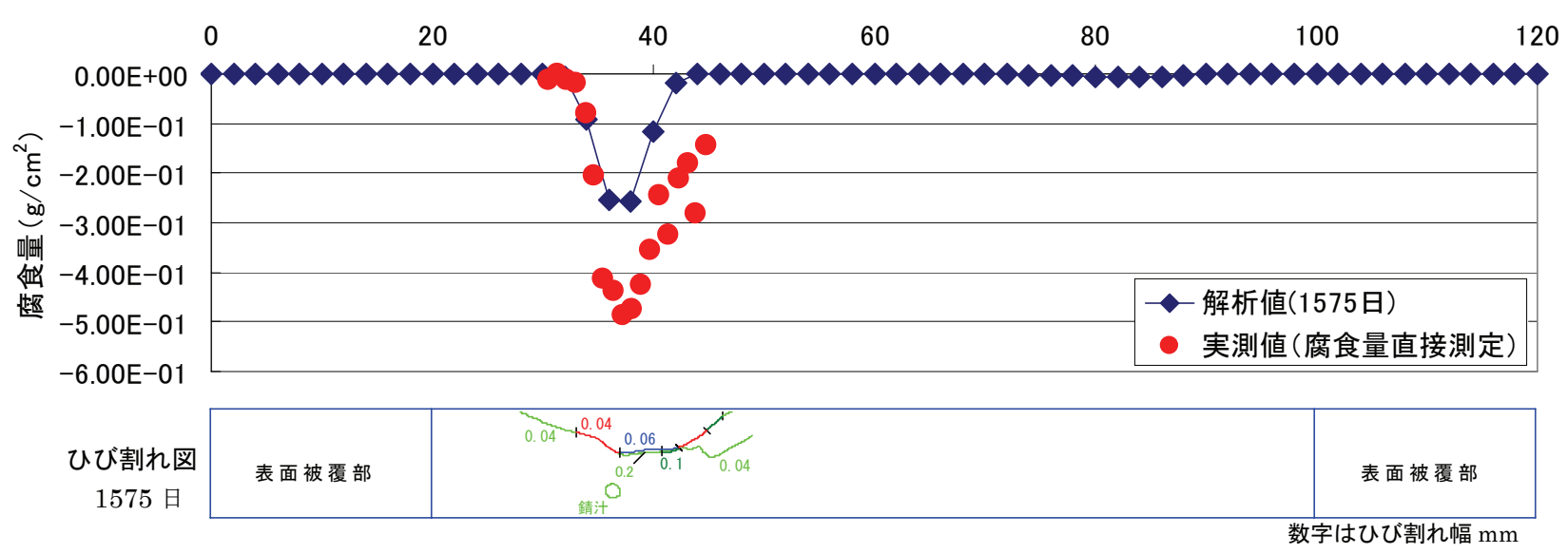

図-25 鉄筋の腐食量の分布に関する実験値と解析值との比較（G-5 室内環境暴露）

供試体上での位置 $(\mathrm{cm})$

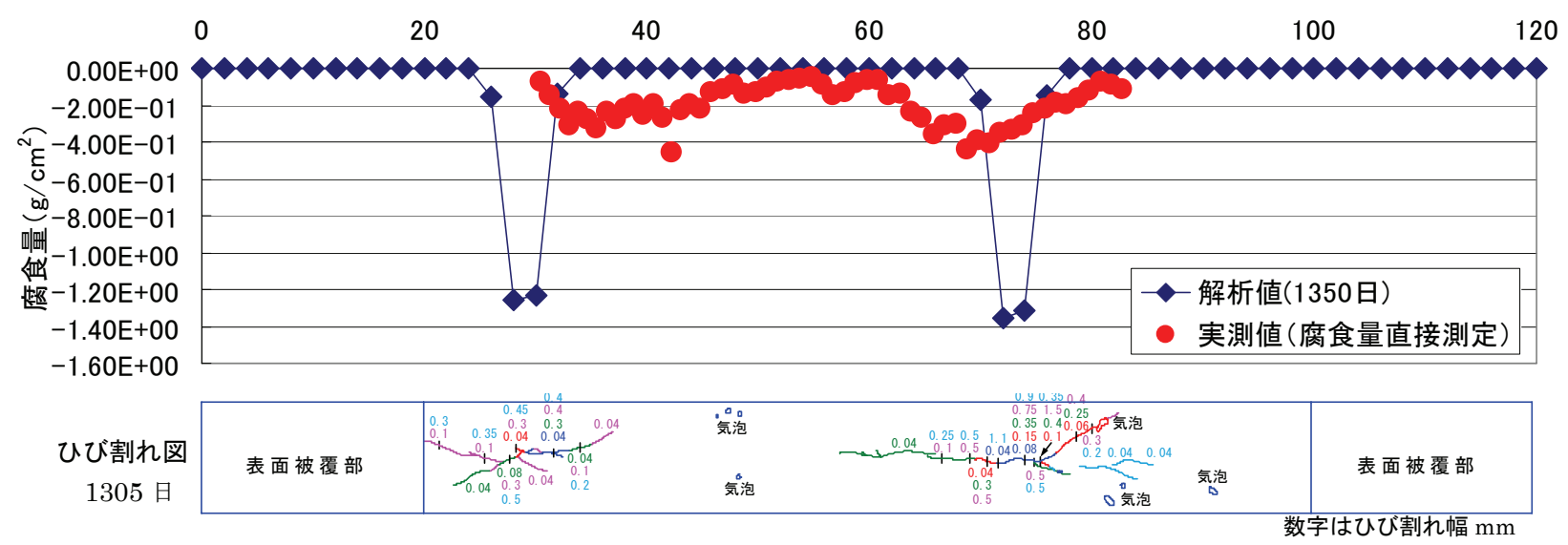

図-26 鉄筋の腐食量の分布に関する実験值と解析值との比較（I-6 海洋環境暴露）

（1）断面修復によるマクロセル回路の形成

a）断面修復部周辺のおける劣化状況

塩化物イオンの影響で鉄筋が腐食して劣化した コンクリートを断面修復する場合，断面修復部分で は鉄筋周辺の塩化物イオンが除去されるため自然電 位が貴となり，断面修復を行っていない部分では塩 化物イオンが除去されないため, 断面修復部分に対 して相対的に自然電位が低くなる。このように，断 面修復部分と未断面修復部分では電位差が生じるた め，これらの間にマクロセル回路が形成されて腐食 電流が流れることになる. 実構造物でもこのような 事実があることは一般に知られており，断面修復部 周辺の未断面修復部で再劣化が生じることが問題と なっている.

b）断面修復部周辺のマクロセル回路形成に関する 考元方

断面修復部周辺の劣化現象に関寸る理論的な検 討としては, Page らによる Evans のダイアグラム を用いた説明がある ${ }^{19)}$ 。これによれば，断面修復部 分に近い未断面修復部分では, 断面修復部分で自然 電位が貴に移行するため, 未断面修復部分の電位も
断面修復部分の電位に影響されて貴に移行し，孔食 電位よりも貴になることによって腐食が進行すると されている.しかし，このような考え方には既にマ クロセル回路の形成が想定されており, Evans のダ イアグラムを用いたミクロセル腐食モデルによる説 明ではマクロセル回路形成による分極状態が考慮で きず不十分であり，峳密には正しくない.

一方，マクロセル回路形成の考え方は図-1 に準拠 しており，断面修復部分および未断面修復部分にお いて鉄筋位置における酸素および塩化物イオン濃度 から求めたミクロセル回路による自然電位の電位差 によりマクロセル回路が形成されるものとした。マ クロセル回路の形成により鉄筋の分極状態が変化す ることにより腐食電流密度が増加し腐食が促進され ることになる。

\section{c）断面修復部周辺の鉄筋の腐食状況}

解析では，図-27 に示すように中央部を断面修復 部分とし，材齢 1000 日まで5章(2)a）と同様な条件 でコンクリートに塩化物イオンと酸素を浸入させた。 また，断面修復は材齢 1000 日で行うとした. 断面修 復時に断面修復部分の塩化物イオン濃度を 0 にする 


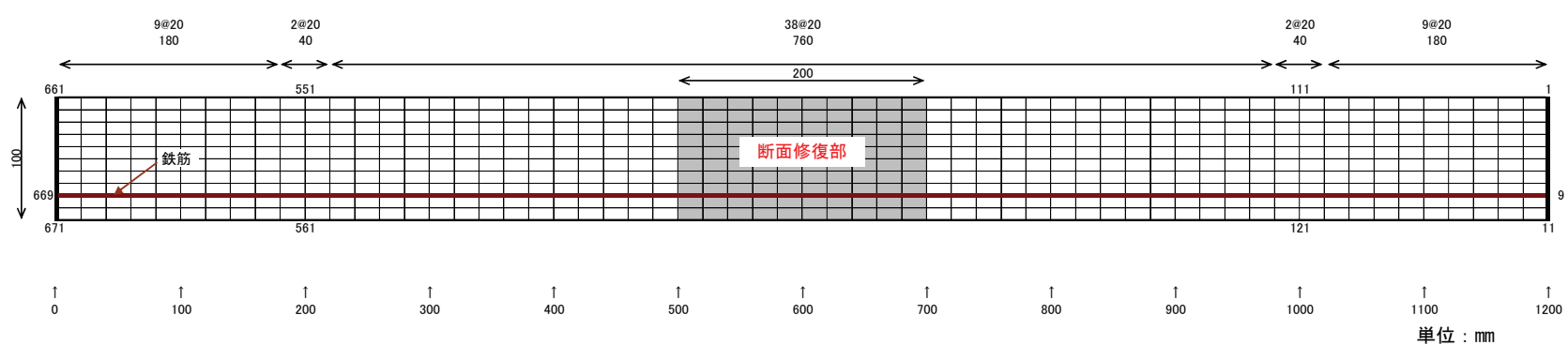

図-27 解析における供試体の要素分割（断面修復想定供試体）

ことによって，未断面修復部分では塩化物イオン濃 度が相対的に高くなる. ただし，材齢 1000 日以降の 断面修復部分における塩化物イオンの拡散係数は未 修復部分と同一とした。

材齢 1400 日，才なわち断面修復後 400 日におけ る液相中の塩化物イオン濃度の分布を図-28に, 自 然電位の分布を図-29に, 累積腐食量を図-30に示寸。 図-28 から断面修復部において液相中の塩化物イオ ン濃度が小さく, 図-29 から断面修復部で自然電位 が未断面修復部分よりも大きいことが示されている。 図-30 からは累積腐食量が最も大きくなる位置は断 面修復部と未断面修復部の界面ではなく，本解析ケ ースに限れば断面修復部から $8 \mathrm{~cm}$ 程度離れた位置で ある. 従来，断面修復部と基体コンクリートの界面 で鉄筋の腐食が激しくなることが言われているが， これは塩化物イオンなどの移動がこの界面でひび割 れ部近傍のように大きくなることが原因である。し かし，マクロセル腐食回路を考慮した場合には，腐 食促進のメカニズムが異なることから, 腐食進行の 激しい箇所が界面ではなく若干離れた箇所になる.

\section{（2） 2 段鉄筋間のマクロセル回路の形成}

a） 2 段鉄筋におけるマクロセル回路形成に関する 考元方

コンクリート表面からの距離が異なる位置に埋め 込まれた 2 本の鉄筋では，コンクリート表面から塩 化物イオンが浸入する場合で，コンクリート表面に 近い鉄筋位置での塩化物イオン濃度が内部の鉄筋に 比較して相対的に大きいとき，コンクリート表面に 近い鉄筋の自然電位が内部の鉄筋に対して相対的に 低くなる。したがって，これら 2 本の鉄筋が電気的 に接続されている場合には, マクロセル腐食回路が 形成され腐食電流が流れる. 既往の研究でも, この ような 2 段鉄筋におけるマクロセル回路の形成と腐 食電流について述べられており 20)，1 本の鉄筋内に おけるマクロセル腐食ではなく, 複数の鉄筋が電気 的につながっている場合のマクロセル腐食について も検討した。

\section{b） 2 段鉄筋それぞれにおける腐食状況}

図-31 に示すように，かぶり $1 \mathrm{~cm}$ および $2 \mathrm{~cm}$ の位

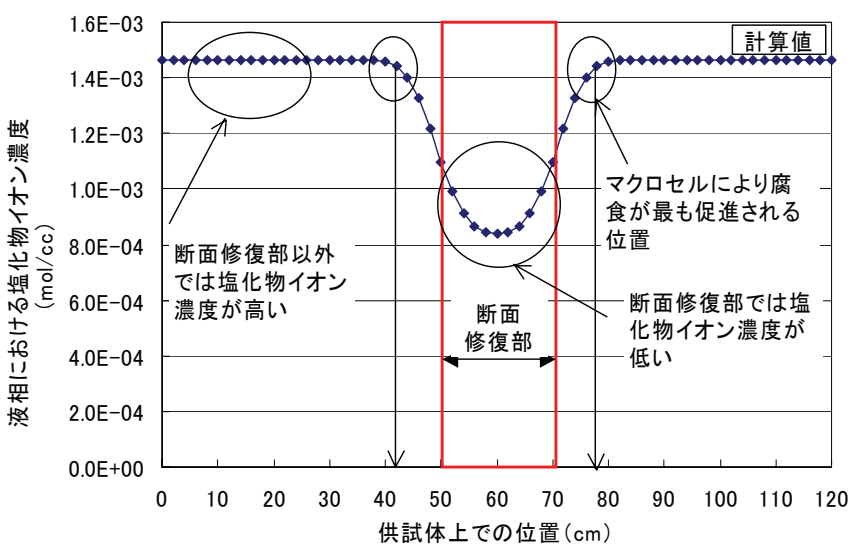

図-28 断面修復想定供試体における液相中の塩化物 イオン濃度の分布

供試体上での位置 $(\mathrm{cm})$

$\begin{array}{lllllllllllll}0 & 10 & 20 & 30 & 40 & 50 & 60 & 70 & 80 & 90 & 100 & 110 & 120\end{array}$

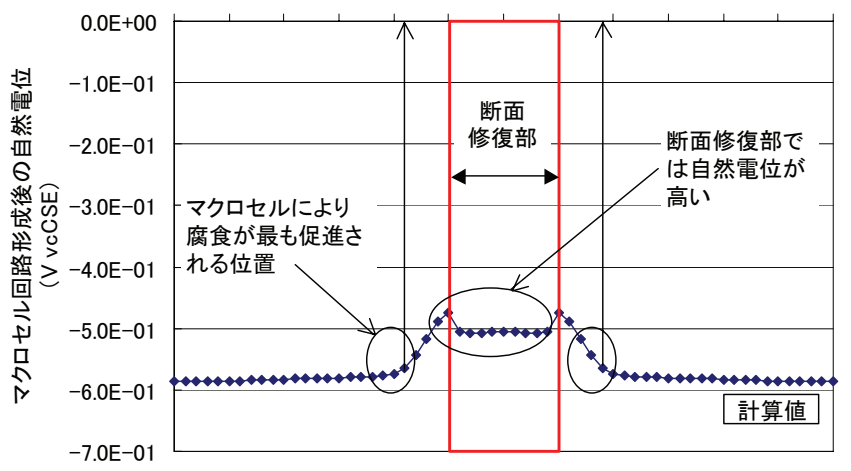

図-29＼cjkstart断面修復想定供試体における自然電位の分布

供試体上での位置 $(\mathrm{cm})$

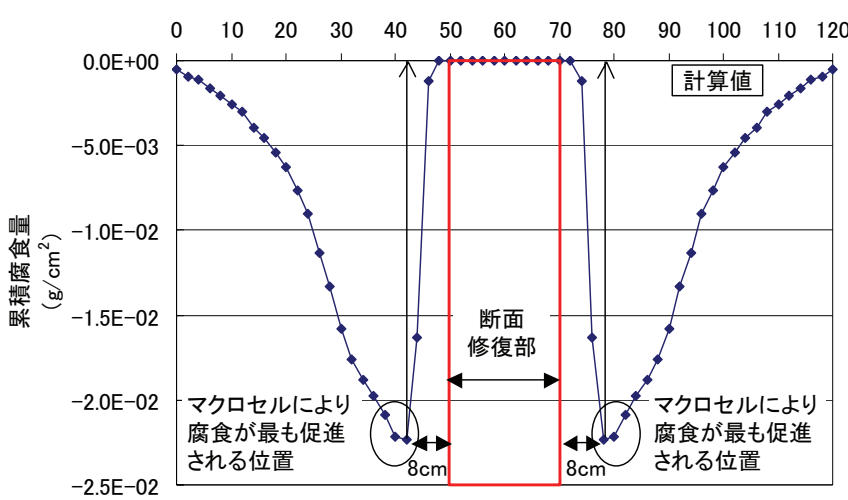

図-30＼cjkstart断面修復想定供試体における累積腐食量の分布 


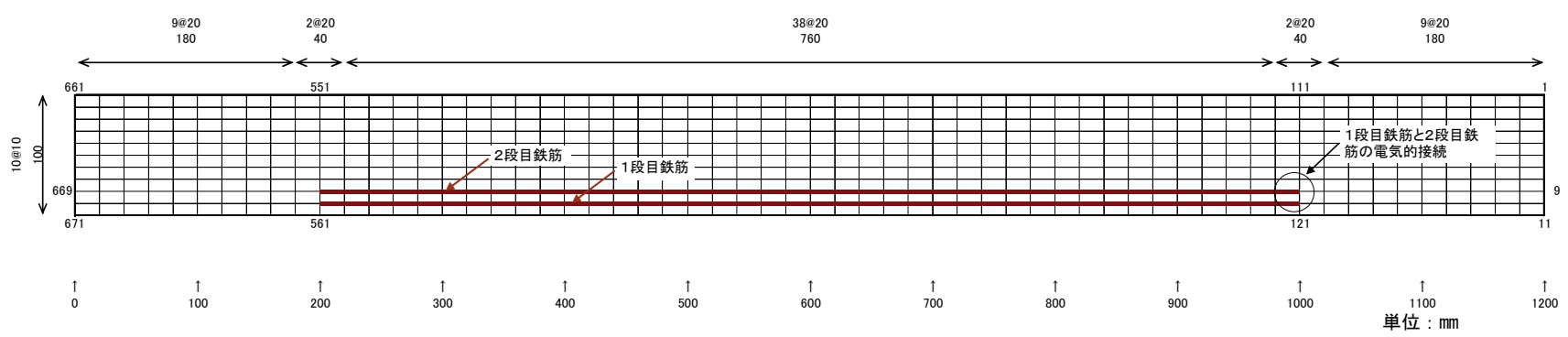

図-31 解析における供試体の要素分割（2 段鉄筋想定供試体）

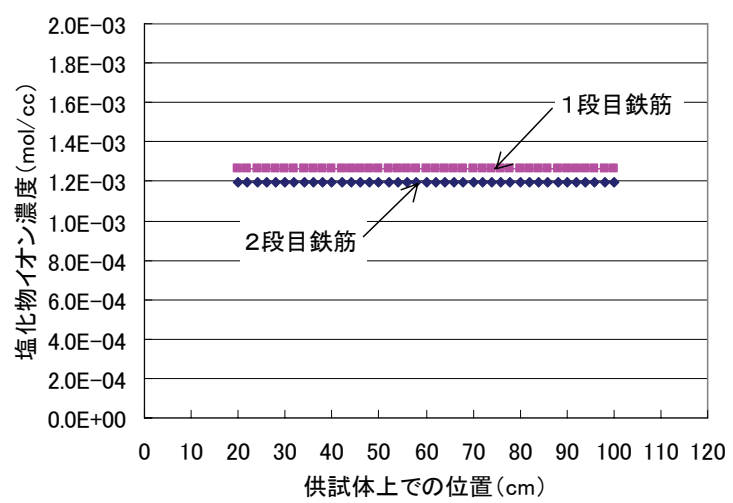

図-32 2 段鉄筋想定供試体における液相中の塩化物 イオン濃度の分布

置に鉄筋を配置した条件で解析を行い，5章 (2)a) と同様な条件でコンクリートに塩化物イオンと酸素 を浸入させ，材齢 1700 日まで計算を行った，材齢 1700 日における液相中の塩化物イオン濃度の分布 を図-32に, 自然電位の分布を図-33 および図-34に, 累積腐食量を図-35 に示す。

図-32 からわかるように，上段鉄筋，下段鉄筋そ れぞれで塩化物イオン濃度の分布は一定である。し たがって，図-33 のミクロセル回路による自然電位 の分布はそれぞれの鉄筋ごとに一定である.しかし， 上下段の鉄筋が電気的に接続している場合には，上 下段の鉄筋間に腐食電流が流れ鉄筋の分極状態が変 化するため, 図-33 および図-34 のマクロセル回路形 成による自然電位のようにミクロセル回路による自 然電位とは異なる自然電位を示す。また，マクロセ ル回路の形成により鉄筋ごとに一定であった自然電 位の分布がそれぞれの鉄筋上でごく微小にではある が異なることになる.

図-35に 1 段目鉄筋における材齢 1700 日の累積腐 食量の分布を示寸。マクロセル回路による腐食は自 然電位が相対的に小さい下段鉄筋で生じており，鉄 筋端部よりも中央部付近で腐食量が大きくなる傾向 を示している．これは，例えば下段鉄筋の中央部と 端部では，上段鉄筋のある要素に対する幾何学的な 最短距離の総和（マクロセル電流が流れるルート） が中央部ほど短くなることから定性的に理解される.
供試体上での位置 $(\mathrm{cm})$

$\begin{array}{lllllllllllll}0 & 10 & 20 & 30 & 40 & 50 & 60 & 70 & 80 & 90 & 100 & 110 & 120\end{array}$

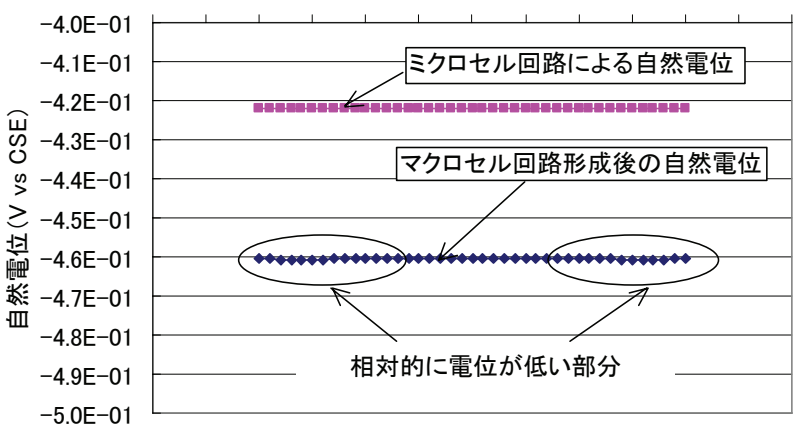

図-33 2 段鉄筋想定供試体における自然電位の分布 ( 2 段目鉄筋)

供試体上での位置 $(\mathrm{cm})$

$\begin{array}{lllllllllllll}0 & 10 & 20 & 30 & 40 & 50 & 60 & 70 & 80 & 90 & 100 & 110 & 120\end{array}$

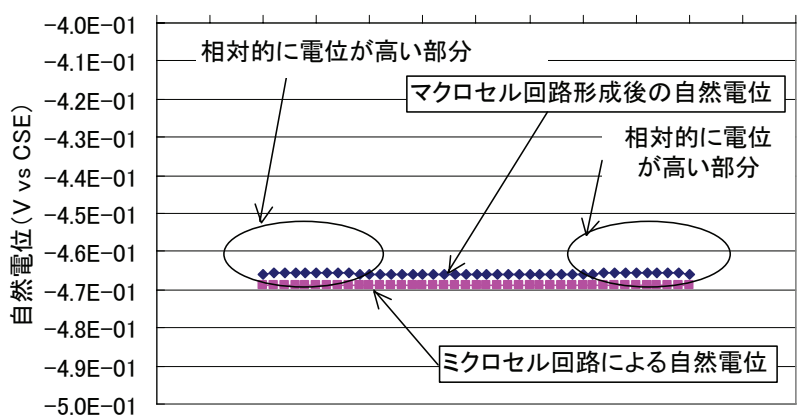

図-34 2 段鉄筇想定供試体における自然電位の分布 ( 1 段目鉄筋)

供試体上での位置 $(\mathrm{cm})$

$\begin{array}{lllllllllllll}0 & 10 & 20 & 30 & 40 & 50 & 60 & 70 & 80 & 90 & 100 & 110 & 120\end{array}$

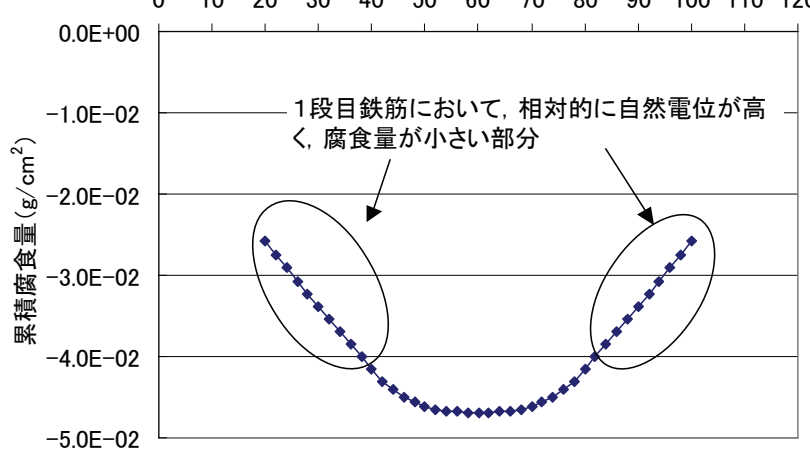

図-352段鉄筋想定供試体における累積腐食量の分布 (1 段目鉄筋) 


\section{7. 結論}

マクロセル回路の形成によるコンクリート中の 鋼材の腐食進行に関する解析手法を構築し，実験に よる手法の検証とマクロセル回路形成を想定した条 件における解析を行った。本研究においては，マク ロセル回路の形成はミクロセル回路の形成にともな う自然電位差に起因すると考えることを基本として いる。これらに関して得られた結論は以下の通りで ある・

（1）マクロセル回路の形成を算出するために必要な アノード分極曲線，カソード分極曲線および孔 食電位を計算するためには，ミクロセル腐食の 現象を適切にモデル化する必要があることを示 し，アノード分極曲線および孔食電位は塩化物 イオン濃度や水酸化物イオンの関数として, カ ソード分極曲線は液相の $\mathrm{pH}$ の関数として, カ ソード反応に関わる限界電流密度は鋼材表面に おける酸素の流束の関数とした.

（2）ミクロセル腐食モデルより算出された自然電位 をマクロセル回路の形成の解析に適用するため に，鋼材上のすべての 2 要素からなる対につい て，その要素間の自然電位差がマクロセル回路 の形成に寄与するとするマクロセル腐食モデル を考案し, 注目要素とそれに対する対要素との 対から計算された自然電位の平均から各要素に おける自然電位を，同じくそれらの対から計算 された電流密度の総和から各要素における電流 密度を算出する手法を構築した。

（3）乾湿繰返し環境に暴露した室内環境暴露供試体 および飛沫带に暴露した屋外海洋環境暴露供試 体の自然電位や腐食量の測定結果を用いること により，ミクロセル腐食モデルおよびマクロセ ル腐食モデルおよび解析手法の検証を行いその 妥当性を明らかにした.

（4）本論文で構築した解析手法により，ミクロセル 回路形成による腐食量よりもマクロセル回路形 成にともなう腐食量が極めて大きくなることが 示された.

（5）本論文で論じた鉄筋腐食量の推定の解析手法に より，断面修復部付近の未断面修復部における 鉄筋の腐食が促進すること，および，2段配筋 部におけるコンクリート表面側の鉄筋の腐食が 促進することを解析的に明らかにできた.

（6）本論文で論じた鉄筋腐食量の推定の重要な指標 であるミクロセル回路における自然電位の推定 精度を向上させるためには,アノード分極曲線, 孔食発生電位, カソード分極曲線を精度よく設 定しなければならない.

\section{参考文献}

1）土木学会 : 2001 年制定コンクリート標準示方書, 維持 管理編，2001.1.

2) Hsu, K.L., Takeda, H. and Maruya, T. : Numerical Simulation on Corrosion of Steel in Concrete Structures Under Chloride Attack, Journal of Materials, Concrete Structures and Pavements, JSCE, No.655/V-48, pp.143-157, 2000.

3) Jones, D.A., Principles and prevention of corrosion, second edition, 1996.

4）土木学会コンクリート委員会腐食防食小委員会：コン クリート技術シリーズ 40 鉄筋腐食・防食および補修 に関する研究の現状と今後の動向（その 2), 2000.

5）大即 信明，宮里 心一，鈴木 裕隆，木村 勇人：曲げ ひび割れ近傍に生じる主鉄筋とスターラップの塩化物 腐食形成機構，土木学会論文集，No.627/V-44， pp.161-177, 1999.

6）長瀧重義, 大即信明, 守分敦郎, 鎌田敏郎, 宮里心一： 断面修復部における打継目の物質通過性が鉄筋のマク ロセル腐食に及ぼす影響, 土木学会論文集, No.578/V-37, pp.31-42, 1997.

7）川東龍夫，小林孝一，宮川豊章：コンクリートに埋設 された鋼材のマクロセルおよびミクロセル腐食に関す る研究，土木学会論文集，No.732/V-59，pp.1-16， 2003.

8) Raupach, M. : Corrosion of steel in the area of cracks in concrete-laboratory tests and calculations using a transmission-line-model, Corrosion of Reinforcement in Concrete Construction, edited by C.L.Page, P.B.Bamforth and J.W.Figg, pp.13-23, 1996.

9) Elsener, B., RILEM TC 154-EMC : 'Electrochemical Techniques for Measuring Metallic Corrosion' Recommendations, Half-cell potential measurements -Potential mapping on reinforced concrete structures, Material and Structures, Vol.36, pp.461-471, 2003.

10）丸屋 剛, Tangtermsirikul Somnuk, 松岡康訓: コンク リート表層部における塩化物イオンの移動に関するモ デル化, 土木学会論文集, No.585/V-38, pp.79-95, 1998.

11) Hsu, K.L., Takeda, H. and Maruya, T. : Numerical simulation on migration of oxygen and carbon dioxide in concrete, Proceedings of Japan Concrete Institute, Vol.20, No.1, pp.769-774, 1998.

12）小山理恵，矢島哲司，魚本健人，星野富夫：自然電位 を用いた鉄筋腐食状態の推定手法に関する基礎的研 究，土木学会論文集，No.550/V-33，pp.13-22， 1996.

13）武若耕司, 小林一輔 : 自然電位法の非破壊的鉄筋腐食 検査手法への実用化について, コンクリート構造物の 耐久性診断に関するシンポジウム論文集, pp.79-84, 1988.

14）（社）日本コンクリート工学協会: コンクリート構造物 
の補修工法研究委員会報告書 (III)， 1996.

15) Bird, H.E.H., Pearson, B.R. and Brook, P.A. : The breakdown of passive films on iron, Corrosion Science, Vol.28, No.1, pp.81-86, 1988

16) Kranc, S.C. and Sagues, A.A. : Modeling the time-dependent response to external polarization of a corrosion macrocell on steel in concrete, J. Electrochem. Soc., Vol. 144, No.8, pp.2643-2651, August 1997.

17) Glass, G.K. and Buenfeld, N.R. : The presentation of the chloride threshold level for corrosion of steel in concrete, Corrosion Science, Vol.39, No.5, pp.1001-1013, 1997.

18）山村浩紀，大津政康：自然電位法のCMS逆解析によ
るコンクリート中の鉄筋腐食の評価に関する研究, コ ンクリート工学年次論文報告集, Vol.15, No.1, pp.739-744, 1993.

19) Page, C.L. and Sergi G. : Development in cathodic protection applied to reinforced concrete, Journal of Materials in Civil Engineering, pp.8-14, February 2000.

20）小林孝一，渡邊佳彦，服部篤史，宮川豊章：高流動コ ンクリートを打ち継いだ塩害コンクリート部材の鉄 筋腐食特性について, 土木学会論文集, No.627/V-44, pp.147-160, 1999.

\title{
SIMULATION OF STEEL CORROSION IN CONCRETE BASED ON THE MODEL OF MACRO-CELL CORROSION CIRCUIT
}

\author{
Tsuyoshi MARUYA, Hitoshi TAKEDA, Kenichi HORIGUCHI, \\ Satoru KOYAMA and Kai-Lin HSU
}

One comprehensive numerical simulation system is proposed for solving the problem of steel corrosion in concrete related to deterioration of reinforced concrete structures under the environment contaminated by chloride ions. Distribution of corrosion amount and corrosion rate along a reinforced bar is calculated based on macro-cell circuit model, which is constituted from micro-cell circuit model. Models are quantified by results of exposure experiments to two environments, one is cyclic wetting and drying in laboratory and the other is splash zone at offshore. The comparisons on time-dependent half-cell potential, corrosion location and corrosion amount indicate the quality coincidence between experimental and analytical results. Examples of calculation on macro-cell corrosion generated between patched area and non-patched area are shown. 